\title{
Human capital, R\&D, trade, and long-run productivity. Testing the technological absorption hypothesis for the Portuguese economy, 1960-2001
}

\author{
Aurora A.C. Teixeira ${ }^{a, *}$, Natércia Fortuna ${ }^{b}$ \\ a CEF.UP, Faculdade de Economia, Universidade do Porto, INESC Porto, Portugal \\ ${ }^{\mathrm{b}}$ CEF.UP, Faculdade de Economia, Universidade do Porto, Portugal
}

\section{A R T I C L E I N F O}

\section{Article history:}

Received 14 August 2006

Received in revised form 12 January 2010

Accepted 20 January 2010

Available online 13 February 2010

\section{Keywords:}

Human capital

Innovation

Trade

Economic growth

Cointegration

\begin{abstract}
A B S T R A C T
An important characteristic of the role of foreign trade in the technological catch-up of countries is the complementary nature with technological change, human capital development and local R\&D efforts. Using cointegration techniques, evidence based on Portuguese long-run growth suggests that by investing in certain capacity-building activities, namely human capital and local R\&D efforts, countries can improve their ability to identify, value, assimilate, and apply (or exploit) knowledge that is developed in other (more developed) countries. Although human capital has a stronger direct impact on total factor productivity than internal R\&D efforts, the latter's indirect impact, by means of machinery and equipment imports, is tremendous. Trade also emerges as a powerful direct contributor to long-term total factor productivity, especially in its embodied form, through the acquisition of advanced machinery and equipment from more developed countries. The (smaller) productivity enhancing effect of licenses and FDI seems to be strongly dependent on institutional circumstances, namely those related to human capital investments and incentives.
\end{abstract}

(C) 2010 Elsevier B.V. All rights reserved.

\section{Introduction}

A number of studies have identified channels through which productivity levels of countries are interrelated, emphasizing the role of international trade (Xu and Chiang, 2005). The primary channels for international technology transfer during the post-war period were trade of capital goods, foreign direct investment (FDI), and licensing (Mowery and Oxley, 1995). Understanding the effective channels of technology diffusion is essential for policymakers in the face of expanding globalization (Zhu and Jeon, 2007).

The possibility of technological transfer is influenced by several factors, namely the social capability of an economy (Abramovitz, 1986), which involves “... various efforts and capabilities that developing countries have to develop in order to catch-up, such as improving education, infrastructures, and, more generally technological capabilities" (Fagerberg and Godinho, 2005: 523). The theory predicts that there may be important interactions between technology imports (in its various forms) and capacity-building activities, such as educational attainment and local R\&D efforts, because technology imports boost productivity only when an economy has a threshold level, in terms of educational attainment or local R\&D effort, that is high enough to

\footnotetext{
* Corresponding author at: Faculdade de Economia do Porto, Rua Dr Roberto Frias, 4200-464 Porto, Portugal. Tel.: +351 225571100; fax: +351 225505050.

E-mail address: ateixeira@fep.up.pt (A.A.C. Teixeira).
}

allow for the efficient use of the imported technology (Mayer, 2001).

A better understanding of a country's real sources of growth requires examining the human capital-R\&D-trade-growth nexus. One of the main problems with empirical studies in this domain is that they do not clearly test the mechanisms through which trade affects total factor productivity. When commenting on the paucity of systematic testing within endogenous growth theory Pack (1994) stressed that using cross-country regressions to explain growth produces irregular orders of magnitude and indications of where to search for explanations of growth, without exploring the connection between factor accumulation and economic growth. In his opinion, " $[t]$ he challenge for empirical work is to test the implications of the ... theory more directly, [i.e.] testing its insights against the economic evolution of individual countries using time series data" (Pack, 1994: 70).

The interrelationship between trade, human capital, local R\&D efforts and growth is likely to be a major issue for Portugal. First, the escalating openness to international trade following World War II is considered an 'inescapable feature' in the development of the Portuguese economy (Barros and Garoupa, 1996). Second, in the same period, the structure of imports changed, revealing a steady upward trend in investment goods (Courakis et al., 1990). These were considered decisive to industrialization both as providers of inputs and as a channel of technological transfer (Afonso and Aguiar, 2005). The other two channels for international technology transfer (FDI and acquisition of foreign licenses) are not as con- 
sensual as to their impact (FDI) nor do they attract much attention (foreign licensing). Resorting to cointegration techniques, in the present paper, we estimate the relative importance of trade, human capital and $R \& D$ (as well as the interaction between the first and the two latter, i.e., the technological absorption hypothesis) on Portuguese long-run growth.

The paper is organized as follows. The next section discusses the theory and empirical literature discussing the potential role of technology imports and the importance of human capital and local R\&D efforts on the economic performance of countries. Section 3 provides some background on the dynamics of Portuguese technology imports and economic growth, and Section 4 discusses the data sources and proxies for the relevant variables. Section 5 highlights our econometric specification and the estimation results, and Section 6 discusses the main conclusions.

\section{Trade, technological change, human capital, and economic growth: a review}

Early catching-up literature, anchored in the neoclassical growth model, suggests that technological transfer is an important source of technological advancement for poor economies (Nelson and Phelps, 1966; Abramovitz, 1986). Advances in the theory of endogenous technological progress have led to a renewed interest in the relationship between trade, technological change, human capital and economic growth. As argued in modern trade literature and integration theory, trade triggers important supply-side effects, which induce efficiency improvements in the enterprise sector and finally lead to additional growth (Grossman and Helpman, 1991). In this context, economies importing goods from other countries with a higher technological level can import technological progress and may be able to renounce their own innovation activity (Rivera-Batiz et al., 1993). Empirically, a number of studies for different set of countries have shown that foreign trade is promoting growth (e.g., Dollar, 1992; Ben-David, 1996). Coe and Helpman (1995) and Coe et al. (1997) consider foreign trade a carrier of knowledge and assess the importance of imports in introducing foreign technology into domestic production and spurring total factor productivity. They assume that a country that is more open to technology imports derives greater benefits from foreign $R \& D$, and show empirically that the countries which have experienced faster growth in TFP have imported more from the world's technology leaders. ${ }^{1}$

Developed countries in general are the global technological leaders. Therefore, imports from these countries are much more likely to embody advanced technology, in particular technology unavailable to firms in less developed countries, than imports from other countries. The contribution of capital goods and imports from developed countries is largely operated through technology transfer effects. According to Lawrence and Weinstein (1999), the role of imports in boosting productivity has been largely ignored due to an excessive focus on the export growth relationship by world authorities (e.g., World Bank). Kim et al. (2009) further assert that with respect to the impact of imports on growth, empirical literature is lagging far behind the theoretical one.

Regarding FDI, a number of studies (e.g., Grossman and Helpman, 1991; Hermes and Lensink, 2003; Batten and Vo,

\footnotetext{
1 Imported technology is expected to have a positive effect on the host country's productivity for several reasons. An important channel by which better-quality technology is obtained is through imported goods, which embody advanced technology (Mendi, 2007; Kim et al., 2009). Thus, total factor productivity (TFP) may increase simply because firms using more advanced technologies raise average productivity; these firms may foster competition among domestic firms, leading to the survival of the fittest; and imported technology may be imitated by local competitors, or even by the licensee, once the licensing contract expires.
}

2009) suggest that it plays an important role in modernizing the economy and promoting economic growth in host countries, especially in developing countries. Since a large share of global R\&D is undertaken by multinational corporations, FDI by these firms is considered a potential channel providing access to advanced technologies available on the global marketplace (Zhu and Jeon, 2007). Theoretically, FDI has been shown to boost economic growth through technology transfer and diffusion (Wang and Blomström, 1992), spillover effects (Wang and Yu, 2007), productivity gains, and the introduction of new processes, managerial skills and know-how in host countries (Girma, 2005), labour turnover (Gershenberg, 1987), or backward and forward production linkages (Markusen and Venables, 1999). Although theoretical models for FDI and technology transfer are well developed (Glass and Saggi, 1998), empirical studies have yielded mixed results (some positive results: Zhu and Jeon, 2007; no evidence: $\mathrm{Xu}$ and Wang, 2000). Several empirical studies indicate that the growth effect of FDI is strongly dependent on the institutional circumstances of the host or receiving countries (Hermes and Lensink, 2003); specifically, they find that FDI inflow is positively associated with economic growth only when countries have previously achieved a certain level of wealth, financial development or educational attainment (Borensztein et al., 1998; Alfaro et al., 2004).

The relationship between FDI and human capital is complex and extremely non-linear (Blomström et al., 2001). Without properly trained or educated human resources, these processes of technology/knowledge transfer and creation, reactive or proactive, cannot occur effectively (Haddad and Harrison, 1993). Borensztein et al. (1998) found a positive link between FDI and growth but only provided that a minimum threshold of human capital has been achieved, corroborating the "absorptive capacity" hypothesis (Cohen and Levinthal, 1989). In line with Borensztein et al.'s (1998) idea of a minimum threshold of human capital, Xu (2000) found that, in the absence of adequate human capital, spillovers (namely of a technological nature, and productivity spillovers) may simply be unfeasible. Therefore, human capital is crucial to enable the spillovers that underpin economic growth. Using a comprehensive panel data set of 79 countries and covering a longer period (1980-2003), Batten and Vo (2009) demonstrate that FDI does in fact have a stronger positive impact on economic growth in countries with a higher level of educational attainment.

Athreye and Cantwell's (2007) findings are consistent with the view that multinationals require the presence of local capabilities and infrastructure before they invest, and that, in more recent times, they tend to follow knowledge-based asset-seeking strategies to reinforce their competitive strengths, as argued by authors such as Cantwell (1989) and Pearce (1999). Competencecreating subsidiaries need to be more closely embedded within local networks (Birkinshaw et al., 1998), and an increased intensity of knowledge exchanges between local actors in these networks tends to create a virtuous cycle of growth in innovation in those favoured locations that have attracted high-quality FDI. Athreye and Cantwell (2007) argue that the international knowledge connections provided by FDI tend to precede and thus facilitate catching-up at higher levels of technological sophistication-FDI promotes technological catch-up among countries that have already acquired sufficient absorptive capacity for higher-order types of innovative activity to take off locally; nevertheless, on average, it tends to have little impact on catching-up in earlier stages of development.

One of the few existing studies relating disembodied technology trade (including patents, licenses for patents, know-how (unpatented knowledge), models and designs, trademarks (including franchising), technical services, and funding of industrial R\&D 
outside national territory, among others) in sixteen OECD countries, from 1971 to 1995 , Mendi (2007) found that the stock of imports of disembodied technology has a positive, statistically significant, effect on productivity in non-G7 countries. This positive effect is stronger in the initial years, and as the effect of imported technology decreases, the effect of the stock of domestic R\&D increases, suggesting that non-G7 countries initially relied on imported technology, and gradually reduced their dependence on foreign technology (Mendi, 2007). This result is consistent with the stock of local R\&D having a non-linear effect on productivity, in the sense that a minimum level in this stock must be reached before any effect on TFP can be observed.

Documenting the considerable importance of technology licensing in the growth processes of countries such as South Korea and Japan, Mowery and Oxley (1995) argue that royalties and licensing imports often require considerable modification by the recipient, and thus reasonable levels of 'absorptive capacity', that is, an ability to understand an externally sourced technology and apply it internally. Nevertheless, they point out that since licensing transactions transfer relatively mature technologies, they tend to be far more important in the early stages of the ('latecomer') countries' industrialization process, strongly based on investments in mature industries (Kim and Dahlman, 1992). Accordingly, the importance of the licensing trade channel would fade as countries undertook efforts to enter more advanced industries that rely on younger technologies. In this latter case, Mowery and Oxley (1995) assert that FDI takes on greater importance as a channel for inward technology transfer.

To sum up, international technology diffusion has not an automatic and direct effect deriving from the existence of a knowledge base in the possession of another country/other firms, it requires the recipient to have the capacity to absorb and adopt such technology (Wang and Blomström, 1992). The 'social capability' (Abramovitz, 1986) and 'absorptive capacity' (Cohen and Levinthal, 1989; Griffith et al., 2003; Narula and Dunning, 2000) of countries cover a complex network of interconnected actors and institutions as emphasized in the literature on systems of innovation (Freeman, 1987; Lundvall, 1992; Nelson, 1993; Breschi and Lissoni, 2001). Thus, there might be important interactions between technology imports, educational attainment and local R\&D efforts, because technology imports boost productivity only when an economy has reached a sufficiently high level of educational attainment or local $R \& D$ efforts that can allow for the efficient use of the imported technology.

\section{The dynamics of Portuguese trade and economic growth}

Several comprehensive studies (Lains, 2003; Afonso and Aguiar, 2005) have documented that the convergence of Portuguese per capita productivity relative to the most developed European countries is an undeniable fact of 20th century economic growth.

Portugal went through various institutional stages during the 20th century (Baer and Leite, 2003): from an inwardly oriented corporatist period (early 1930s to the early 1960s), a late corporatist-liberalizing phase in the decade spanning the early 1960 s to the early 1970 s, the revolutionary period of $1974-1975$, with substantial nationalization and re-distributive measures, to the post-revolutionary years spanning the second half of the 1970s to the mid-1980s, and entering the EEC (1st January 1986), with the gradual adoption of neo-liberal economic policies and a massive influx of structural funds.

In the period 1960-1973 the Portuguese economy displayed the typical characteristics of a New Industrialised Country (NIC) (Krugman and Macedo, 1979), i.e., very fast economic growth based mainly on international trade expansion and imports of capital inputs. The impact of openness on economic development was considerable. Between 1960 and 1973, Portuguese GDP per capita grew from one third to half that of the most developed European countries (Gonçalves, 1998).

The second half of the 1970s and the mid-1980s was a difficult period for Portugal, marked by the absence of convergence, and dominated by a politicized market economy with strong intervention from the Government, particularly in price determination. At a time when global recession had set in brought on by two oil shocks, Portugal had to contend with the economic and social impact of the 1974 revolution. These events implied new legislation that profoundly altered labour relations, the dismantling of big economic groups that dominated most sectors of the economy, the independence of the African colonies, and the overall revolutionary climate (Castro, 2004). In 1985 - a year before Portugal joined the (then) EEC - relative GDP per capita was similar to that of 1971 (Gonçalves, 1998).

After entering the EEC (and until the mid-1990s), the convergence process resumed at approximately the same rate as in the period 1961-1973, largely due to the global boom from 1986 to 1989 and joining the EEC, factors which led to wide-ranging reforms to liberalize the economy and open it to foreign trade and investment (Mateus, 2005). In the first half of the 1990s, significant inflows of FDI were channelled predominantly into the manufacturing sector, involving some emblematic projects such as the large car plant, the Ford-Volkswagen Auto Europa Project. ${ }^{2}$

Since the mid-1990s, economic developments in Portugal have been irregular. In the late 1990s significant imbalances built up, notably a sharp rise in the net borrowing of the economy which became a major cause for concern. The sharp rise in labour costs was not supported by corresponding advances in labour productivity. Labour productivity growth in Portugal has generally followed a downward trend, falling behind the EU average from 2000 onwards (EC, 2004).

Despite over two decades of EU membership, Portugal's GDP per capita remains around $60 \%$ that of the most developed European countries. Such a disappointing performance is profoundly linked to the sluggish evolution of the economy's productivity, whose most crucial underlying causes are various structural characteristics (Silva and Teixeira, 2009). In particular, the labour force's level of schooling, investment in (business) R\&D and innovation have remained low in comparison with other EU Member States (EC, 2004). National productive specialization, (still) based on lowtechnology activities and routine production (EC, 2004), made the demand for and investment in qualified human capital, above all by enterprises, superfluous (Godinho and Simões, 2005). The inadequate level of domestic skills stemming from this represent, in turn, one of the main barriers to entrepreneurial innovation, restricting not only the firms' capacity to innovate and absorb technology from abroad, but also the intensity and cognitive level of the relationships established with other organizations, namely universities and research centres (Teixeira and Costa, 2006).

Our argument here is that the dynamics of the Portuguese economy is a strikingly illustrative case of the complex, non-linear interrelationships that exist between trade, human capital, local R\&D efforts and growth; moreover it highlights the relevance of capacity-building activities - human capital and local R\&D - in determining the ability of a nation to carry out innovation (and

\footnotetext{
2 The subsidiary Auto Europa, which resulted from a Ford-VW joint venture (presently belonging only to $\mathrm{VW}$ ), was, up to the present, the main foreign investment in Portugal comprising 2.5 billion euros. Although this project generated important clustering effects, bringing 22 other FDI projects and having since then attracted additional domestic and foreign investment to its cluster, in general, the restricted impact of new technology-generating activities by subsidiaries located in Portugal resulted in increased vulnerability and has led to a higher risk of divestment in these projects (Tavares and Young, 2005).
} 


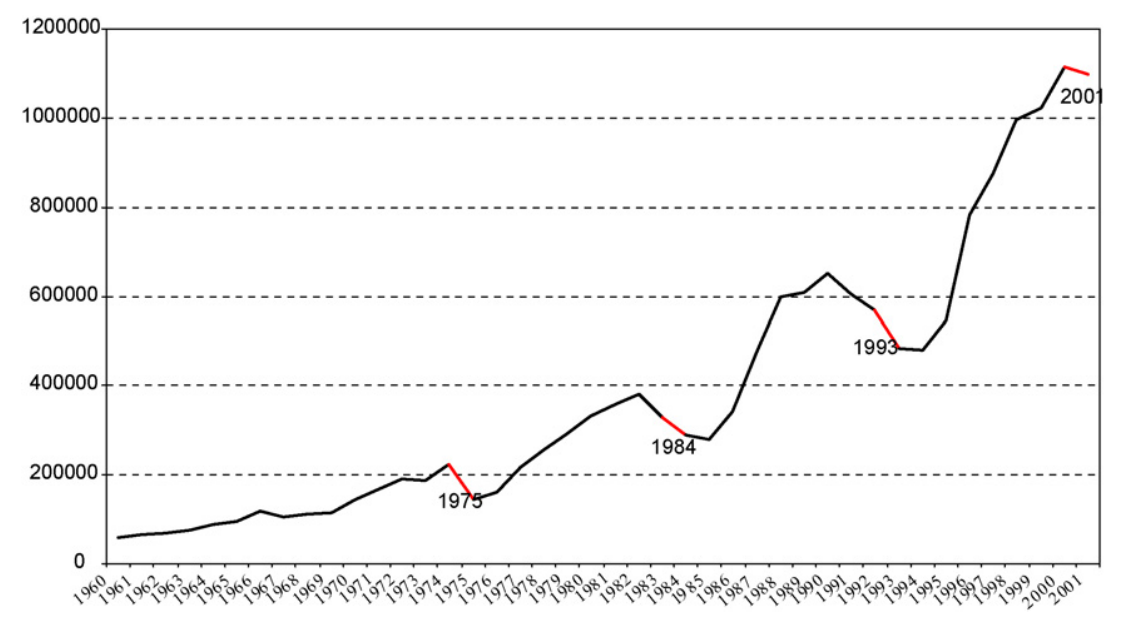

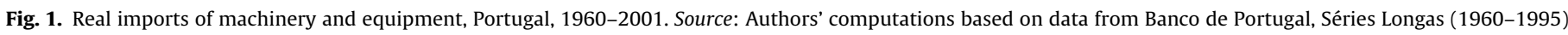
and INE (1996-2001).

directly impact on TFP) and in contributing to the assimilation of (advanced) technology from abroad, indirectly impacting on TFP (i.e., supporting the technological absorption hypothesis).

Portuguese technological (capital goods) imports (encompassing machinery, transport equipment and other capital goods imports), in their majority from more technologically advanced countries, have gained considerable importance over the last 40 years, and comprised around $40 \%$ of total imports in 2000 , rising from $21.5 \%$ in 1960 (in the case of machinery, the figures were, respectively, $22 \%$ and $13.5 \%$ ).

Taken both in real terms (Fig. 1) and as a ratio of GDP (Fig. 2), machinery and equipment imports revealed considerable dynamism in the period under study, with average annual growth rates of $7.3 \%$ and $2.9 \%$, respectively. This dynamism is even more remarkable over the 1993-2000 period, presenting average growth rates of $12.7 \%$ and $7.8 \%$, respectively.

Inward FDI flows (in percentage of the GDP), although rather irregular in character, also revealed strong dynamism over this period, growing on average at an annual rate of $6.2 \%(7.7 \%$ in 1993-2000) (Fig. 3). Portugal did not attracted much FDI until the end of the 1950s, but a profound change in policy when Portugal joined EFTA as a founding member in 1960, opened the country to trade and investment, embracing internationalization as the engine for growth (Lopes, 1996). The opening of the Portuguese economy was further consolidated with GATT membership in 1961, and was accompanied by a new policy towards FDI, even though it did exclude a substantial number of industries considered sensitive by the government (Castro, 2004). The newly established foreign subsidiaries were important providers of much-needed capital and a means by which to access new markets, contributing decisively to the diversification of the country's industrial structure (Gonçalves and Guimarães, 1997). Although the 1974 revolution did not directly affect foreign-owned firms, the political, social and economic climate was not however favourable to investment. In a profoundly adverse international environment, the ratio of inward FDI to GDP dropped every year between 1975 and 1980. EU membership (1986) was a critical moment for Portugal as it represented free access to a consolidating single market from a lowlabour cost platform and the assurance of economic and political stability. Prompted by new international conditions, a privatization programme, better infrastructure, and EU-sponsored incentives for new projects in manufacturing, tourism and agriculture, inward FDI flows were especially high between 1988 and 1993. A slowdown in the privatization programme, the European recession, and the fall of communism in Central and Eastern Europe brought about a shift in Portugal's position in Europe's geopolitical map, partly justifying the marked decline in FDI inflows in the second half of the 1990s. In the early 2000s, inward FDI was redirected from the industrial sector to the services one, particularly financial services and telecommunications.

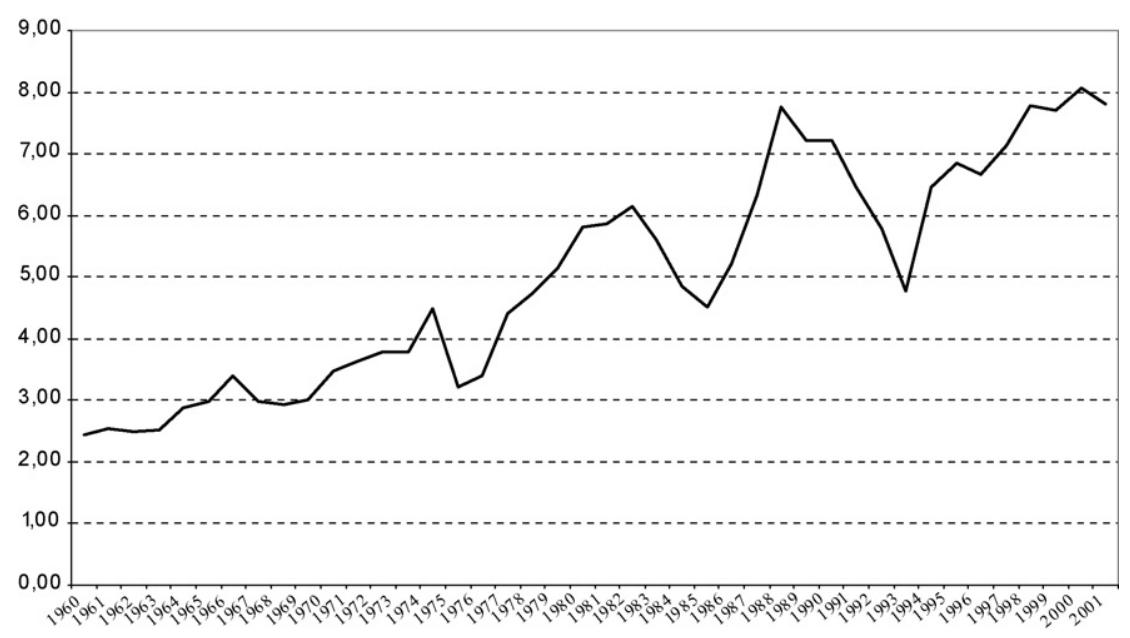

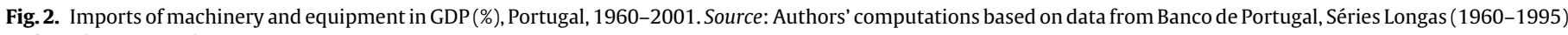
and INE (1996-2001). 


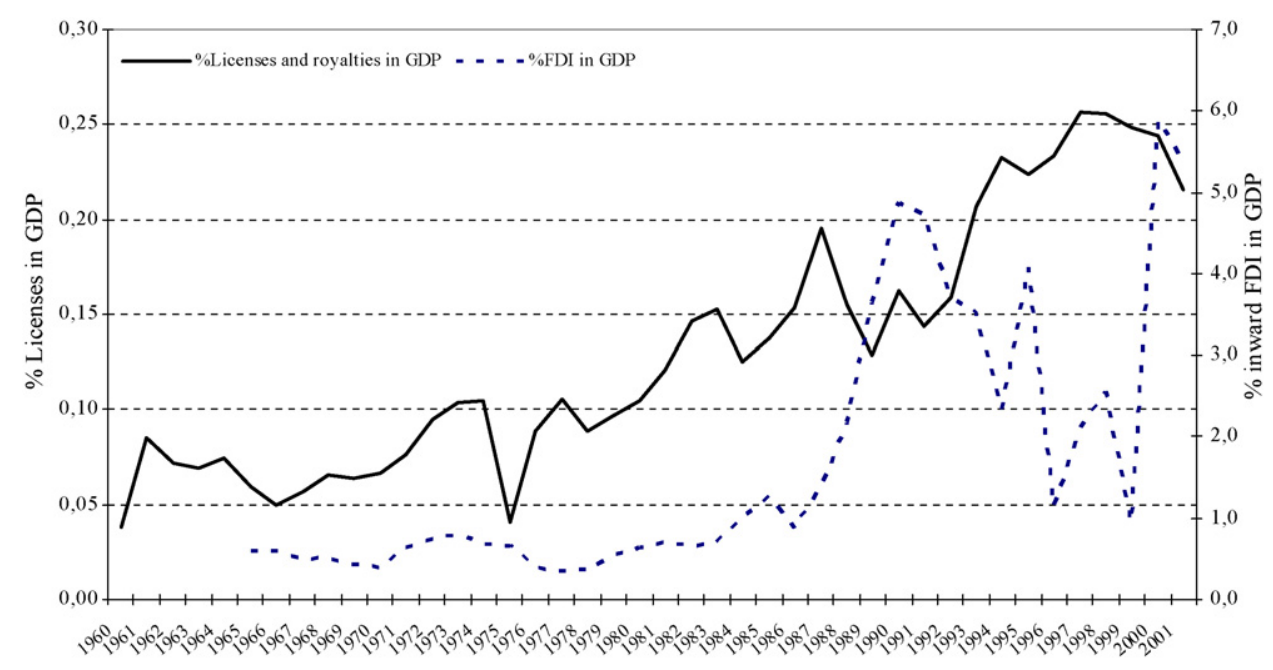

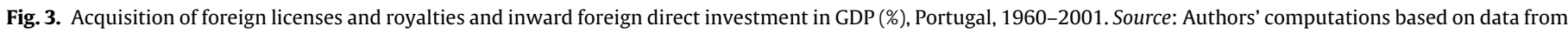
Banco de Portugal, Séries Longas (1960-1995) and INE (1996-2001).

The trade of disembodied technology measured by royalties and licensing imports (Mendi, 2007) includes the purchasing of patents, licenses for patents, know-how, models and designs, trademarks, and technical services (OECD, 1999). It provides a reliable indicator for both the acquisition of technology (Archibugi and Cocoa, 2005) and the value of the intellectual property rights used (Athreye and Cantwell, 2007). This channel accounts for a modest share in Portugal's total international technology transfer, representing only $0.13 \%$ of the GDP for the entire period considered. Nevertheless, a clear upward trend (as a percentage of GDP) was verified (Fig. 3), with an annual average growth rate of $4.3 \%$. Although this trend may indicate that licensing transactions were, in the Portuguese case, not only important in the early stages of the 'latecomer' pattern of industrialization, as in the case of Japan and South Korea (Kim and Dahlman, 1992), it does to some extent contrast with the experience of these latter countries, as it continued (and even increased in importance) to play a relevant role in subsequent phases, coinciding with efforts to enter more advanced industries that rely on newer technologies and in which FDI become a more important channel for inward technology transfer (Mowery and Oxley, 1995).

In order to test whether in the long run the potential interactions between capacity-building activities (educational attainment and local R\&D efforts) and technology imports are likely to positively impact on a country's total factor productivity and thus to better understand the real sources of Portuguese economic growth, we will examine the human capital-local R\&D-trade-growth nexus. The estimation of the cointegration relationship requires building proxies for the relevant variables-total factor productivity, human capital, local R\&D, and technology imports. The next section briefly describes the proxies used.

\section{Proxies for the relevant variables}

\subsection{Total factor productivity (TFP)}

The most commonly used measures of a country's economic performance are output per worker (or hours per worker), i.e., labour productivity, and total factor productivity (TFP) or "residual of Solow" (Teixeira and Fortuna, 2004). Output per worker measures productivity growth as the difference between the growth rate in the output index based on gross domestic product (GDP) at constant prices and an employed population index or the num- ber of hours per worker. The second measure, TFP, subtracts from the first measure an estimate of the contribution of physical capital to productivity growth, based on the growth of the capital/labour ratio, weighted by the capital factor share on total returns relative to all the factors. Labour productivity is a partial measure which does not allow for the inclusion of the effect of factor substitution between capital and labour (Kim et al., 2009). This effect is especially important for the Portuguese economy, which has continuously experienced capital deepening and adoption of new production technologies (Mateus, 2005). Measures of labour productivity generally include the effects of capital deepening, along with technological progress and structural efficiency changes that determine TFP. Therefore, we use TFP, rather than labour productivity, as our measure of productivity in order to determine the effects of trade on structural and technological changes.

\subsection{Human capital stock}

A review of the measures of the stock of human capital used in empirical growth research reveals that human capital is generally poorly proxied, and measurement problems are particularly acute when it comes to this variable (Wößmann, 2003).

Alternative proxies for human capital include school enrolment ratios, adult literacy rates, levels of educational attainment and average years of schooling, monetary value of human capital stock and students' international test scores (Teixeira, 2005). The first two proxies were extensively used in growth regressions (Mankiw et al., 1992) on the grounds of their easy availability and broad coverage. However, adult literacy rates ignore most of the investments made in human capital as they do not include qualifications obtained beyond the basic levels of education. In relation to school enrolment ratios, they are a poor measure of the stock of human capital available for current production. Enrolment ratios are flow variables, and children currently enrolled in schools are by definition not yet part of the labour force. Therefore, enrolment ratios may not even accurately represent changes in human capital stock, especially during periods of rapid educational and demographic transition. The two last proxies (monetary value of the human capital stock, international test scores) are at present restricted by the limited size of the sample. Therefore, data on educational attainment still provide the best available information on a country's level of human capital stock. Educational attainment is clearly a stock variable, and it takes into account the total amount of the labour 
force's formal education. ${ }^{3}$ This study uses average years of schooling of the working-age population as a proxy for human capital stock following the methodology detailed in Teixeira (2005).

\subsection{Domestic RED efforts}

Knowledge stock has been approximated by various proxies: number of scientists and engineers (Jones, 1995), patented inventions (Fagerberg, 1987), strength of R\&D-R\&D/GDP ratio (Griliches, 1988), total expenditure on R\&D (Coe et al., 1997), among others. Fagerberg (1987) divides measures of technological level and technological activities into technological input measures (expenditures on education, expenditures on R\&D, employment of scientists and engineers) and technological output measures (patents). Measures of the first type are directly related to the innovation capability of a country and also to its own capacity for imitation, such that the science base has to achieve a certain level for the imitation process to be successful. Technological output measures are only related to innovation activity-the innovation of methods of production and output.

Here, we favour technological input measures (more precisely, accumulated expenditures on R\&D) because economic growth in Portugal has been more specifically characterized by the absorption and diffusion of knowledge, rather than by its creation (Verspagen, 1993). In line with the empirical work of Coe and Helpman (1995), we use business accumulated expenditures on R\&D as a proxy for local R\&D efforts or knowledge stock. Teixeira (2007) presents the details of the methodology applied and the estimation results for this proxy.

\subsection{Technology imports and the technological absorption hypothesis}

Guided by insights from the literature on R\&D endogenous growth models and systems of innovation, we evaluate the contribution of three main channels of technology diffusion - embodied (machinery and equipment imports) and disembodied (imports of licenses, royalties, and alike) technology transfer, and FDI - to total factor productivity (TFP). The indicators/proxies considered for the three trade channels are quite conventional and widely used, being computed as shares in the country's GDP: machinery and equipment imports in GDP (Lawrence and Weinstein, 1999; Kim et al., 2009); imports of licenses, royalties and alike in GDP (Athreye and Cantwell, 2007; Mendi, 2007); inward foreign direct investment flows in GDP (Zhu and Jeon, 2007; Batten and Vo, 2009).

As reviewed earlier, the degree of (international) technology diffusion depends on the "absorptive capacity" of each country (Savvides and Zachariadis, 2005). At the macroeconomic level, absorptive capacity reflects the fact that international technology (knowledge) transfer does not benefit all countries equally, or one country equally at all times. The benefits enjoyed by countries (and their local organizations) are determined in part by the countries' own actions (policies) and resources (Fabrizio, 2009), in particular, its capacity to invest in research and other capacity-building activities, namely R\&D and human capital, in order to improve its ability to identify, value, assimilate, and apply (or exploit) knowledge that is developed in other countries. In spite of the strong theoretical basis for the significant role a country's absorptive capacity plays in its growth, Meyer (2003: 22) recognizes that "the full [empir-

\footnotetext{
${ }^{3}$ Nevertheless, specifying human capital by average years of schooling means that any year of schooling acquired by a person implicitly bears the same weight and ignores the fact that one year of schooling does not raise the human capital stock by an equal amount, regardless of the quality of the education system providing it (Wößmann, 2003).
}

ical] potential of the concept of absorptive capacity is yet to be exploited".

We posit, in line with Benhabib and Spiegel (1994: 145), that human capital and local R\&D efforts play a dual role in promoting total factor productivity: first, by enabling a country to “... directly influence productivity by determining the capacity of nations to innovate new technologies suited to domestic production"; second by enhancing the "... capacity of a country to absorb foreign technology allowing a country to close the gap between the current level of productivity and that of the leading technology country."

Thus, in addition to including human capital and domestic R\&D efforts as a direct determinant of TFP growth, we also include interactional effects between human capital/local R\&D efforts and foreign technology sources, in order to effectively test the technological absorption hypothesis. Accordingly, it is expected that a more highly educated workforce can better take advantage of foreign R\&D-induced ideas, and is also more likely to use capital goods and licensing imports (embodying advanced foreign technologies) more effectively. Following similar reasoning, by investing in R\&D activities, organizations can improve their (and ultimately their country's) ability to exploit (assimilate and apply) knowledge developed externally (Coe and Helpman, 1995; Fabrizio, 2009).

Based on the insightful analysis of Mowery and Oxley (1995), it is reasonable to expect that, depending on the country's position and social framework, different modes of (international) technology transfer - embodied (machinery and equipment imports) and disembodied (imports of licenses, royalties, and alike) technology transfer, and FDI - place different demands on the absorptive capacity of countries and therefore distinctively impact on total factor productivity. Thus, the interaction variables between human capital (local R\&D efforts) and international trade channels, which proxy distinct (yet interrelated) absorptive capacity dimensions, may emerge differently in relation to total factor productivity.

\section{Specification and estimation of the econometric model}

\subsection{Specification of the econometric model}

The purpose of this section is to estimate the long-run structural relations between total factor productivity, human capital, local R\&D efforts, and trade (machinery and equipment imports; royalties and licensing imports; inward foreign direct investment) for the Portuguese economy in the period 1960-2001.

These structural relations are based on a log-linear specification of the joint evolution of total factor productivity (proxy for technological progress), machinery and equipment imports/licenses/FDI (proxies for technology diffused from more technologically developed countries), human capital stock (average number of years of schooling), and local/domestic R\&D efforts (internal stock of business R\&D activities):

$$
f_{t}=\beta_{1,0}+\underbrace{\beta_{1,1} h_{t}+\beta_{1,2} r d_{t}}_{\begin{array}{c}
\text { Internal capability building } \\
\text { activities }
\end{array}}+\underbrace{\beta_{1,3} \text { trade }_{t}}_{\begin{array}{c}
\text { International } \\
\text { trade }
\end{array}}+u_{1 t},
$$

where $f_{t}$ is the (natural) logarithm of the total factor productivity level, for the year $t$; $h_{t}$ is the logarithm of the average number of years of schooling (proxy for human capital) for the year $t ; r d_{t}$ is the logarithm of the index of business R\&D stock (proxy for local/domestic R\&D efforts) for the year $t$; trade trepresents $_{\text {imach }}$ r $\left(\mathrm{lic}_{t}\right)\left[f d i_{t}\right]$, i.e., the logarithm of machinery and equipment imports (royalties and licensing imports) [inward FDI] in GDP, for the year $t ; \beta_{1,1}, \beta_{1,2}$ and $\beta_{1,3}$ are the TFP elasticities with respect to human capital stock, R\&D stock and capital goods/licenses imports/inward FDI, respectively; and, finally, $u_{1 t}$ is a random perturbation term. 
The theory suggests that productivity tends to increase when human capital stock $(h)$ or knowledge stock $(r d)$ grows, ceteris paribus. It also suggests that greater technology diffusion from abroad, reflected by more imports of capital goods (namely machinery and equipment, imach/licenses/inward FDI), is associated with higher productivity. Therefore, productivity will be positively related to human capital, domestic knowledge stocks and technology imports, that is, $\beta_{1,1}>0, \beta_{1,2}>0$ and $\beta_{1,3}>0$.

If the theory is valid, we expect that any departure in productivity, with regard to long-run equilibrium (expressed by the equation above), will necessarily be of a temporary nature. Therefore, an additional basic assumption of the theory is that the sequence $u_{1 t}$ is stationary.

In order to analyze potential interactions between human capital, domestic R\&D efforts and imports of advanced technology from abroad, that is, the technological absorption hypothesis, the following relation is also estimated:

$\begin{aligned} f_{t}= & \beta_{2,0}+\underbrace{\beta_{2,1} h_{t}+\beta_{2,2} r d_{t}}_{\begin{array}{c}\text { Internal capability building } \\ \text { activities }\end{array}}+\underbrace{\beta_{2,3} \text { trade }_{t}}_{\begin{array}{c}\text { International } \\ \text { trade }\end{array}} \\ & +\underbrace{\beta_{2,4} \text { htrade }_{t}+\beta_{2,5} \text { rdtrade }_{t}}_{\begin{array}{l}\text { Technological absorption } \\ \text { capability }\end{array}}+u_{2 t},\end{aligned}$

where trade $_{t}=H_{t}$ trade $_{t}$ with the index $H_{t}$ of the average number of years of schooling for the year $t$; rdtrade $_{t}=R D_{t}$ trade $_{t}$ with the index $R D_{t}$ of the local business stock of R\&D (knowledge) for the year $t$.

If $\beta_{2,4}, \beta_{2,5}>0$, then the effect of technology imports (trade channels) on productivity tends to be greater when the population is more educated and local/domestic R\&D efforts are higher; or, in other words, the effect of human capital stock and local R\&D efforts on productivity is directly related to the magnitude of the acquisition of advanced technology from abroad (the technological absorption hypothesis).

Variables for total factor productivity, human capital, local R\&D efforts and technology imports display strong trends, that is, they are non-stationary. In this case, the use of conventional estimation methods (based on the classical hypotheses of perturbation terms) in models that include such variables, tend to lead to erroneous statistical inference (Rao, 1994). The statistical reliability of classical estimation methods is based on the hypothesis that the variables means and variances are well defined, as well as being time-independent constants. However, when means and variances change with time (non-stationary variables), all statistics that use these means and variances will also be dependent on time and therefore do not converge to the true (population) values when sample size tends towards infinity. Moreover, hypothesis tests, based on these statistics, will also be biased towards the rejection of the null hypothesis of absence of a relation between the dependent and independent variables. Thus, in the presence of nonstationary variables, the use of conventional estimation methods also brings the risk of obtaining "spurious regression" (Granger and Newbold, 1974), whose estimates are deprived of any economic meaning. Studies based on time series analysis (Engle and Granger, 1987) highlight cointegration techniques as the most adequate estimation method when the variables of a model are non-stationary.

Given the inherent non-stationary character of the series in our study, we concluded that the use of classical estimation methods would be unsatisfactory and, guided by the latest econometric advances in time series analysis, we opted for the use of cointegration techniques.

\subsection{Estimation of the model}

Cointegration enables the possibility of estimating equilibrium, or long-run parameters, in a relationship that includes unit root (non-stationary) variables. In this study, the use of this econometric analysis is motivated, on the one hand, by an interest in estimating long-run relationships between total factor productivity, human capital and capital goods imports and, on the other, by the statistical properties of the time series considered. The econometric EViews $5.0^{\circledR}$ software was used in the estimation. The time series employed exhibit strong trends, noticeable in Fig. A1 (in Appendix $A$ ), which are confirmed by the tests for non-stationarity (presented in Tables A2-A4 in Appendix A).

The idea behind cointegration is that, in the long run, if two or more series evolve together, then a linear combination among them may become stable around a fixed mean, despite their individual trends (which cause non-stationarity). Thus, when there is a long-run relationship between variables, the regression of all the variables (cointegrating regression) has stationary perturbation terms, even though no variable, individually considered, is stationary. ${ }^{4}$

The results of the Augmented Dickey-Fuller (ADF) (Dickey and Fuller, 1981) and Phillips-Perron (PP) (Phillips and Perron, 1988) tests applied to the variables in this study, indicate that the twicedifferenced series are stationary (Table A2), that is, the variables will be integrated, at most, to the second order, i.e., I(2). Comparing the values of the test statistics obtained with the corresponding critical values, we conclude that all variables differenced once are stationary (that is, they do not have unit roots) (Table A3). Thus, it is reasonable to assume that all the series in the model are at most I(1). Finally, we can conclude from Table A4 that the (level) variables of the model are non-stationary (the statistical evidence does not reject a non-stationarity hypothesis-the existence of a unit root).

From the findings described above, we can conclude that the model's series are I(1). Consequently, the series could perhaps be cointegrated (Dickey et al., 1991), that is, there could be one or more stationary linear combinations of the series, suggesting a stable long-run relationship between them.

Since the number of cointegration vectors is unknown, and since it is necessary to guarantee that all the variables are potentially endogenous (and then test for exogeneity), it seems advisable to use the methodology developed by Johansen (Johansen and Juselius, 1990).

As mentioned above, the structural regression to be estimated involves a relationship between productivity (TFP), human capital stock, domestic R\&D stock, and technology imports for the Portuguese economy in the period 1960-2001, expressed by (1) and (2). In cointegration notation, using Model (2) in its full version [see $\left(2 \mathrm{~d}^{\prime}\right)$ in Table 2], the vectors of potentially endogenous variables $z_{t}$ and the normalized cointegrating vectors $\beta$ 's can be represented as

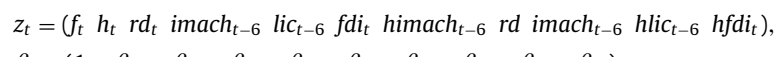

$\beta_{i}=\left(1-\beta_{1 i}-\beta_{2 i}-\beta_{3 i}-\beta_{4 i}-\beta_{5 i}-\beta_{6 i}-\beta_{7 i}-\beta_{8 i}-\beta_{9 i}\right)$.

In order to carry out the cointegration test, it was necessary assume that there is a certain trend underlying our data. We allowed for a deterministic linear trend in the level data, but the cointegrating equations only have intercepts because we believe all

\footnotetext{
${ }^{4}$ In technical terms, the class of non-stationary series contains a special group made up of integrated known variables, having important statistical properties of significance at the level of economic relationships. A series $y_{t}$ is said to be integrated at order $d$, denoted by $I(d)$, if $\Delta^{d} y_{t}=(1-L)^{d} y_{t}$ is a stationary series (where $L$ is a backshift operator: $\left.L y_{t}=y_{t-1}\right)$. In other words, a series is integrated to the order $d$ if it becomes stationary when differenced $d$ times.
} 
Table 1

Results of Johansen's cointegration test. Portugal, 1960-2001.

Note: MacKinnon et al. (1999) $P$-values.

\begin{tabular}{llllll}
\hline$r$ & $\hat{\lambda}_{i}$ & $\lambda_{\text {trace }}$ & $P$-value & $\lambda_{\max }$ & $P$-value \\
\hline None & 0.978554 & 492.2127 & 0.0000 & 134.4779 & 0.0000 \\
At most 1 & 0.957736 & 357.7348 & 0.0000 & 110.7336 & 0.0000 \\
At most 2 & 0.873877 & 247.0012 & 0.0000 & 72.46755 & 0.0002 \\
At most 3 & 0.766377 & 174.5336 & 0.0000 & 50.89156 & 0.0148 \\
At most 4 & 0.644763 & 123.6421 & 0.0002 & 36.22395 & 0.1276 \\
At most 5 & 0.583542 & 87.41813 & 0.0011 & 30.65897 & 0.1155 \\
At most 6 & 0.541029 & 56.75916 & 0.0059 & 27.25691 & 0.0550 \\
At most 7 & 0.406597 & 29.50225 & 0.0540 & 18.26586 & 0.1202 \\
At most 8 & 0.256265 & 11.23639 & 0.1974 & 10.36244 & 0.1892 \\
At most 9 & 0.024661 & 0.873943 & 0.3499 & 0.873943 & 0.3499 \\
\hline
\end{tabular}

$(2 \mathrm{~d}) /\left(2 \mathrm{~d}^{\prime}\right):$

$$
f_{t}=\beta_{3,0}+\underbrace{\beta_{3,1} h_{t}+\beta_{3,2} r d_{t}}_{\begin{array}{c}
\text { Internal capability building } \\
\text { activities }
\end{array}}
$$

$$
+\underbrace{\beta_{3,3} \text { imach }_{t}+\beta_{3,4} l i c_{t}+\beta_{3,5} f_{d i i_{t}}}_{\begin{array}{c}
\text { International } \\
\text { trade }
\end{array}}
$$

$$
+\underbrace{\beta_{3,6} \text { himach }_{t}+\beta_{3,7} r \operatorname{dim} a h_{t}+\beta_{3,8} h_{\text {lic }}+\beta_{3,9} h f d i_{t}}_{\begin{array}{l}
\text { Technological absorption } \\
\text { capability }
\end{array}}+u_{3 t} .
$$

trends are stochastic. In the period $1960-2001$, the $\left(\lambda_{\text {trace }}\right.$ and $\left.\lambda_{\max }\right)$ tests do not reject the hypothesis that there are four cointegrating vectors (cf. Table 1) at conventional significance levels.

The Johansen procedure was applied to test whether there is a cointegration relationship between TFP, human capital, local R\&D efforts, machinery imports, and the variables proxying the absorption capability (as described in (1) and (2)). Since this involves technology transference from the 'frontier' countries (e.g., the US, Japan, and Germany) to a more laggard country (Portugal), we want to allow for a time lag in the transfer of knowledge through technology imports (of machinery and licenses), in the methodological line of Kocherlakota and Yi (1997). ${ }^{5}$ Thus, alternative specifications are estimated using the lagged import variable. ${ }^{6}$ This conveys the empirically reasonable idea that the absorption of new technology from abroad, and the corresponding impact on productivity, requires a considerable amount of time (Mowery and Oxley, 1995; Savvides and Zachariadis, 2005). While here estimates for six lags are reported, we experimented with alternative lag structures and (the results) confirm the robustness of the estimates computed.

In Table 2, we present nine sets of estimations, five [(1)-(2a) ... (2d)] involving the current and four $\left[\left(1^{\prime}\right)-\left(2 a^{\prime}\right)-\left(2 c^{\prime}\right)-\left(2 d^{\prime}\right)\right]$ other lagged values of trade channels - in the case of FDI, only current values ( $2 \mathrm{~b}$ ) were considered. In the full econometric specifications [models $(2 \mathrm{~d})$ and $\left(2 \mathrm{~d}^{\prime}\right)$ ], all three trade channels of international technology transfer were included - machinery and equipment imports, licenses and royalties, and foreign direct investment - plus the corresponding human capital interaction variables, himach, hlic and $h f d i$. Local business R\&D efforts were also taken into account. When we leave out the human capital variable and include R\&D as a unique capacity-building activity, combined with the three trade channels, no long-run relations emerge. Moreover, the R\&Dmachinery imports interaction variable is, for the period in analysis, the single, most statistically relevant interaction between local R\&D efforts and international trade channels. Given these facts, and for the sake of simplicity, the following specification, expressed in its reduced form, is presented (in Table 2) as our full Model

\footnotetext{
5 In the case of FDI we do not consider time lags for two orders of reasons: (1) the FDI time series is shorter (1965-2001) than the other series; if we considered time lags the series would become even shorter, calling into question the robustness of the econometric analysis; (2) existing studies which analyze the FDI-productivity/growth nexus in their majority do not consider time lags (e.g., Chakraborty and Nunnenkamp, 2008) or, when they do (e.g., Stanisic, 2008), they use non-lagged and $2-3$ period lagged variables, concluding that results do not differ between lagged and non-lagged scenarios.

${ }^{6}$ The general specification, according to Eq. (2), generated over 18 distinct models by combining the three trade channels with the two internal capacity-building activities (human capital and R\&D).
}

In the case of the full (lagged) specification [Model $\left(2 \mathrm{~d}^{\prime}\right)$ ], setting $r=4$, we obtain the estimates of the cointegrating vectors. Normalizing each of the four cointegrating vectors with respect to total factor productivity, the four long-run equilibrium relationships are then obtained. Selecting the "most significant" cointegrating vector (Dibooglu and Enders, 1995), the estimates of the cointegrating vector $\left(2 \mathrm{~d}^{\prime}\right)$ are obtained. ${ }^{7}$

According to the economic theory underlying the model, TFP is positively related to an economy's stock of human capital, local R\&D efforts, and technology imports (diffusion of advanced technology from abroad). Moreover, the long-run parameter associated with the variable that takes into account interactions between human capital/R\&D stock and technology imports from abroad, for instance, himach or rdimach, is also theoretically expected to be positive, meaning that the elasticity of total factor productivity with respect to internal stock of knowledge $\left(\beta_{3,6} \mathrm{H}\right.$ or $\left.\beta_{3,7} R D\right)$ is greater for higher levels of schooling of the population or for higher levels of local/domestic R\&D efforts. In other words, the influence of machinery imports on productivity is a positive function of the economy's human capital and business R\&D stocks.

According to the results, the estimated cointegration relationships are consistent with the theoretical assumptions, especially when we consider lagged technology imports from abroad. Thus, it takes time, in the Portuguese case around 6 years, for machinery imports to (directly and indirectly) impact on total factor productivity. In the case of royalties and licensing imports, it is the current rather than the lagged values which reveal positive and significant long-run correlations with TFP [cf. Model (2d)]. Although they may entail considerable modification by the recipient (Mowery and Oxley, 1995), royalties and licensing imports involve relatively mature technologies, already available/known to the world, which justifies to some extent their (direct and indirect) simultaneous impact on TFP.

The view that the 'social capability' of a nation matters when explaining a nation's innovation capability (i.e., the level of TFP) is clearly supported by the findings. In particular [cf. fully lagged Model $\left.\left(2 \mathrm{~d}^{\prime}\right)\right]$, there is strong statistical evidence that the quality of the innovation system, as measured by human capital investments and local R\&D efforts, plays an important role both directly, by enhancing internal technological capabilities, and indirectly, by helping domestic organizations to understand and decode foreign technology, that is, it enhances

\footnotetext{
${ }^{7}$ In the face of 'multiple cointegrating vectors', Dibooglu and Enders (1995) recommend the selection of the "most significant" cointegrating vector, that is, the one which is more in accordance with the theoretical assumptions. An identical procedure was followed to obtain the remaining long-run cointegrating vectors presented in Table 2.
} 
Table 2

Estimates of the long-run TFP elasticities. Portugal, 1960-2001.

\begin{tabular}{|c|c|c|c|c|c|c|c|c|c|c|}
\hline & & \multicolumn{5}{|c|}{ Current imports/licenses/FDI } & \multicolumn{4}{|c|}{ Lagged imports/licenses } \\
\hline & & $\overline{(1)}$ & $(2 a)$ & (2b) & $(2 \mathrm{c})$ & $(2 d)$ & $\overline{\left(1^{\prime}\right)}$ & $\left(2 a^{\prime}\right)$ & $\left(2 c^{\prime}\right)$ & $\left(2 d^{\prime}\right)$ \\
\hline \multicolumn{11}{|c|}{ Internal capability building activities } \\
\hline$h$ & Human capital direct effect & 0.035 & & & -0.143 & $0.112^{* *}$ & $0.249^{* * *}$ & $0.152^{*}$ & -0.846 & $0.376^{* * *}$ \\
\hline rd & Local R\&D efforts direct effect & & & & 0.314 & 0.255 & & & $0.795^{* * *}$ & $0.238^{* * *}$ \\
\hline \multicolumn{11}{|c|}{ International trade (diffusion of superior technology from abroad) } \\
\hline imach & Imports of machinery & 0.244 & & & 0.070 & $0.634^{* * *}$ & $0.313^{*}$ & & $0.564^{* * *}$ & $0.862^{*}$ \\
\hline lic & Licenses and royalties acquired to foreign & & & & & $0.013^{* * *}$ & & $0.258^{* * *}$ & & -0.105 \\
\hline fdi & Foreign direct investment & & & & & -0.350 & & & & -0.462 \\
\hline \multicolumn{11}{|c|}{ Technology absorption capability } \\
\hline himach & Human capital indirect effect, through imports of machinery & 0.687 & & & -0.110 & -0.850 & $0.333^{* * *}$ & & -1.636 & -1.257 \\
\hline rdimach & Local R\&D indirect effect, through imports of machinery & & & & 0.178 & $0.464^{* * *}$ & & & $0.826^{* *}$ & $0.811^{* * *}$ \\
\hline hlic & Human capital indirect effect, through imports of licenses and royalties & & & & & $0.170^{* * *}$ & & $0.119^{*}$ & & -0.081 \\
\hline hfdi & Human capital indirect effect, through inward FDI & & & & & 0.382 & & & & $0.634^{*}$ \\
\hline & Long-run cointegration? ${ }^{\mathrm{a}}$ & Yes & No & No & Yes/No ${ }^{b}$ & Yes & Yes & Yes & Yes & Yes \\
\hline
\end{tabular}

a The cointegration test is specified with two lags in level series and a linear deterministic trend.

b Cointegration according to trace test and no cointegration according to Max-eigenvalue test.

Significant at $10 \%$ level.

** Significant at $5 \%$ level.

*** Significant at $1 \%$ level.

absorbing capabilities. The 'openness' of the national innovation system also emerges as highly relevant in boosting innovation capability.

Results based on macro-data for the Portuguese economy in the period from 1960 to 2001 demonstrate that human capital and domestic R\&D efforts are key prerequisites for the country's technological absorption capabilities. This contrasts with Verspagen's (1993) earlier account that in the process of economic growth in small, open economies, such as Portugal's, local innovation efforts are not (as) fundamental. However, later, Verspagen, jointly with Fagerberg (Fagerberg and Verspagen, 2002), recognized that conditions for catching-up had become severe over time, putting greater pressure on domestic innovation efforts in many countries.

The results further show that trade, namely (lagged) machinery and equipment imports, (current) royalties and licensing imports, and inward FDI, impact positively on growth because they encourage a higher level of technological absorption. More specifically, the impact of embodied technology (machinery and equipment imports), disembodied technology (royalties and licensing imports) and inward FDI on the country's productivity is all the greater, the higher the local R\&D effort (in the case of machinery imports) and the more skilled the human capital (in the case of licenses and FDI), which allows for an efficient use of the imported technology.

Foreign trade in the form of machinery and equipment imports has been, for the Portuguese economy, a true carrier of knowledge' (Coe and Helpman, 1995; Coe et al., 1997). The results support that increasing openness to capital imports derives greater benefits to Portuguese TFP from foreign innovation capabilities. Similarly to Kim et al. (2009), who focused on the South Korean economy, in the period 1980-2003, we found that imports have a significant positive effect on TFP, being by far the largest contributor among the distinct trade channels considered [see estimates of the coefficients associated to imach, lic and fdi, in Models (2d) and $\left(2 \mathrm{~d}^{\prime}\right)$ ]. Our findings thus suggest that learning, innovation and competitive pressures resulting from foreign capital imports are important vehicles for growth. The macro-link hypothesized by Chong and Zanforlin (2002) between newly transferred technologies and productivity by means of machinery and equipment imports is corroborated by the Portuguese long-term data. Accordingly, a critical mass of know-how may be required to successfully absorb technology from abroad. The data seems therefore to sustain that the impact of new technology as embodied in machinery imports on total factor productivity is significant if complementary technological developments are in place, namely an adequate amount of local business R\&D efforts. Note that the long-run elasticity associated with the corresponding proxy for technology absorption capability achieves the highest figure, 0.811 percentage points. Although there is some evidence that human capital also seems to be necessary for foreign machinery to be efficiently adopted [in Model $\left(1^{\prime}\right)$, the estimate of the interaction variable himach is positively and significantly correlated to TFP], in the sense that highly educated workers are able to adapt more rapidly to the new, (presumably) more sophisticated technology imported from foreign countries, when we include the interaction variable rdimach (proxying the indirect effect of local R\&D by means of machinery imports on TFP), the human capital-machinery imports interaction variable ceases to be statistically significant. It is important to stress, however, that this is likely to reveal the fundamental complementarity between R\&D investments and human capital in the process of building research capacity (Aghion et al., 2009); indeed, local R\&D efforts tend to put pressure on the demand for scientists and engineers, thus depending, to a large extent, on a positive supply response from the educational system, i.e., large amounts of highly qualified human capital.

In line with Mendi (2007), the longitudinal data on Portugal show that current [Model (2d)], and, when considered as a single trade channel, the lagged [Model $\left(2 \mathrm{a}^{\prime}\right)$ ] disembodied technology trade (which includes the imports of patents, licenses for patents, know-how (unpatented knowledge), models and designs, trademarks (including franchising), technical services, and funding of industrial R\&D outside national territory), have a positive and statistically significant impact on Portuguese long-run productivity, albeit rather small in magnitude. Moreover, there is also slight evidence [Models $(2 d)$ and $\left(2 a^{\prime}\right)$ ] that the indirect effect of disembodied technology imports has played a reasonably relevant role in the enhancement of Portuguese TFP in the four decades considered, although such an effect is rather negligible when compared to that associated to machinery and equipment imports [see the estimates for himach and hlic in Models ( $\left.1^{\prime}\right)$ and $\left(2 \mathrm{a}^{\prime}\right)$, respectively]. This result is consistent with the idea that the stock of human capital has a nonlinear effect on productivity, in the sense that a minimum level in this stock must be reached before any effect on TFP through the imports of disembodied technology can be observed (corroborating once more the technological absorption hypothesis). 
Results regarding inward FDI indicate, in line with Hermes and Lensink (2003) and Borensztein et al. (1998), that FDI inflows are strongly dependent on the institutional circumstances of the host or receiving country, in particular, FDI is positively associated with economic performance only when a country has previously achieved a certain level of formal educational attainment (Borensztein et al., 1998)-the interaction variable between human capital and inward FDI ( $h f d i)$ is positively and significantly related to total factor productivity [cf. Model $\left(2 \mathrm{~d}^{\prime}\right)$ ], showing a long-run elasticity of 0.634 . Thus, FDI only impacts on TFP if properly trained or educated human resources are available; if this is not the case, as highlighted earlier by Haddad and Harrison (1993), these processes of technology/knowledge transfer and creation, reactive or proactive, associated to FDI cannot occur effectively. Thus, there is indeed a positive link between FDI and growth but only provided that a minimum threshold of human capital has been achieved (Borensztein et al., 1998; Xu, 2000), which corroborates the technological absorption capacity hypothesis.

\section{Conclusions and policy implications}

In the present paper we constructed empirical, testable specifications which accounted for both the direct and indirect (through technology imports) impact of human capital on the long-run total factor productivity of a country.

The results obtained for the period 1960-2001 showed that the direct effect of human capital is quite substantial and higher than that of local business R\&D efforts. However, the indirect effect of local R\&D effort through lagged capital goods imports emerged as even more critical for Portuguese long-run total factor productivity (TFP). Among the three trade channels considered, machinery and equipment imports have in fact had the greatest and most significant (direct and indirect) impact on TFP. This is not to say that the remaining trade channels are inconsequential, quite the opposite. Portugal's catching-up process is depicted here as a complex process where the distinct trade channels seems to contribute (to differing degrees), by means of technological absorption, to its long-run total factor productivity. The evidence based on the Portuguese case suggests that trade channels as carriers of foreign technological knowledge and capabilities are complementary rather than substitutes. It also goes against the idea that some channels are more important in one stage of development than in another. We have undoubtedly collected solid evidence that for Portugal, classified in the 1960s-1970s (similarly to other NICs such as South Korea), as a 'followership' and 'latecomer' country, machinery and equipment imports continue to be a stalwart 'engine' of growth. However, the 'fuel' is presently more intimately related with the country's business R\&D efforts, rather than the simple achievement of a given minimum level of (formal) educational attainment. What is in place therefore is not so much a quest for the passive adoption of foreign technology (as a supposedly essential requirement in the early stages of latecomers' catching-up process), but an imperative for the active development of domestic innovation capabilities which enable the country to take advantage on what is being develop inside and elsewhere, and forging ahead. Thus, the catching-up process in itself has developed a more complex and harsh context, placing increasing demands on technological capabilities and innovation efforts (Fagerberg and Verspagen, 2002). Disembodied technology (measured by current royalties and licensing imports) and inward FDI also impact on Portuguese total factor productivity but the magnitude of the effect is lower (than that of machinery imports) and operate mainly through human capital investment, highlighting the positive role human capital plays in the absorption of international technological advances, favouring the technological absorption hypothesis.
These findings have interesting policy implications and call for a 'redefinition' of the role of government as the prime agent of change, aiming to provide not only the essential economic and institutional framework, but also the long-term vision, national consensus and collective trust that determine a society's inner dynamism (Aubert and Reiffers, 2003).

Public policy plays an important role in shaping a country's national innovative capacity (Furman et al., 2002). But, it is not only a question of simply increasing the level of formal (quantitative) education and $R \& D$ resources available to the economy, as a more restricted interpretation of our results may possibly convey; other policy choices, as detailed below, are key to productivity dynamics, as they have huge potential in shaping human capital investment and innovation incentives (Svarc, 2006).

The relevance of human capital for Portuguese technological enhancement and economic growth as documented in earlier studies (Teixeira and Fortuna, 2004; Mateus, 2005; Pereira and St Aubyn, 2009) has been clearly confirmed here. Additionally, corroborating the results of micro-level studies focusing on the relationship between human capital and FDI for Portugal (e.g., Tavares and Teixeira, 2005) and FDI-human capital-growth for a large set of countries (Batten and Vo, 2009), we found that human capital is crucial to enable the FDI spillovers that underpin economic growth. However, low levels of schooling and qualifications represent one of the most serious obstacles to the development of the country, one of the major reasons for the low, non-convergent level of productivity and the divergent trajectory that Portugal has shown when compared to European standards. Despite improvements in recent years, Portugal is still one of the poorest performers in terms of educational attainment of the working-age population. ${ }^{8}$ Labour market dynamics have favoured low-skilled workers and have not contributed to enhancing education as a factor in increasing employability. This deficit in the importance given to higher educational levels corresponds to a structural weakness within the Portuguese economy and society and favours the early entry of unqualified or semiskilled workers into the labour market (CSF III Observatory, 2007). Increasing human capital is essential to improve the adaptability of the workforce to ongoing structural transformations and to foster stronger productivity growth (OECD, 2008). Portugal suffers from a large educational gap vis-à-vis the rest of the OECD countries and action is required not only to raise the population's level of educational attainment, but also to review the type of education provided and its quality (OECD, 2008; Pereira and St Aubyn, 2009). ${ }^{9}$

Given the proven (direct and indirect) relevance of domestic business R\&D efforts in TFP, public authorities need to take the lead in fostering innovation in industrial sectors by allocating more resources to support and encourage domestic R\&D activities (combining tax-relief policies for business R\&D with subsidies for

\footnotetext{
${ }^{8}$ In 2001, only one fifth of the population aged between 25 and 64 had completed upper secondary education or beyond (compared to, on average, more than three-fifths on average in the EU and OECD countries) (EC, 2004). Levels of vocational training in Portugal are also clearly lower than in other EU countries. In 2005 only $4.6 \%$ of the adult Portuguese population attended any type of lifelong learning course, whereas the average for the EU-15 was $11.9 \%$ and EU-25 $10.8 \%$.

9 Data from the OECD Programme for International Student Assessment PISA (OECD, 2008) reveal that the quality of education systems in countries such as Portugal and Argentina is quite bad, in contrast to those of Finland and South Korea. It shows that the ability of Portuguese youths (15-year-olds about to finish compulsory schooling) to use their knowledge and skills in order to meet real-life challenges is significantly below the OECD average. In terms of reading literacy among students, Portugal ranks 26th in a total of 32 countries (OECD, 2003). Similar results were observed in mathematical and in scientific literacy tests (Portugal ranks 28th). Poor achievement levels among students currently in school call for immediate policy attention, because they suggest that skill shortages may persist as a long-term problem in Portugal.
} 

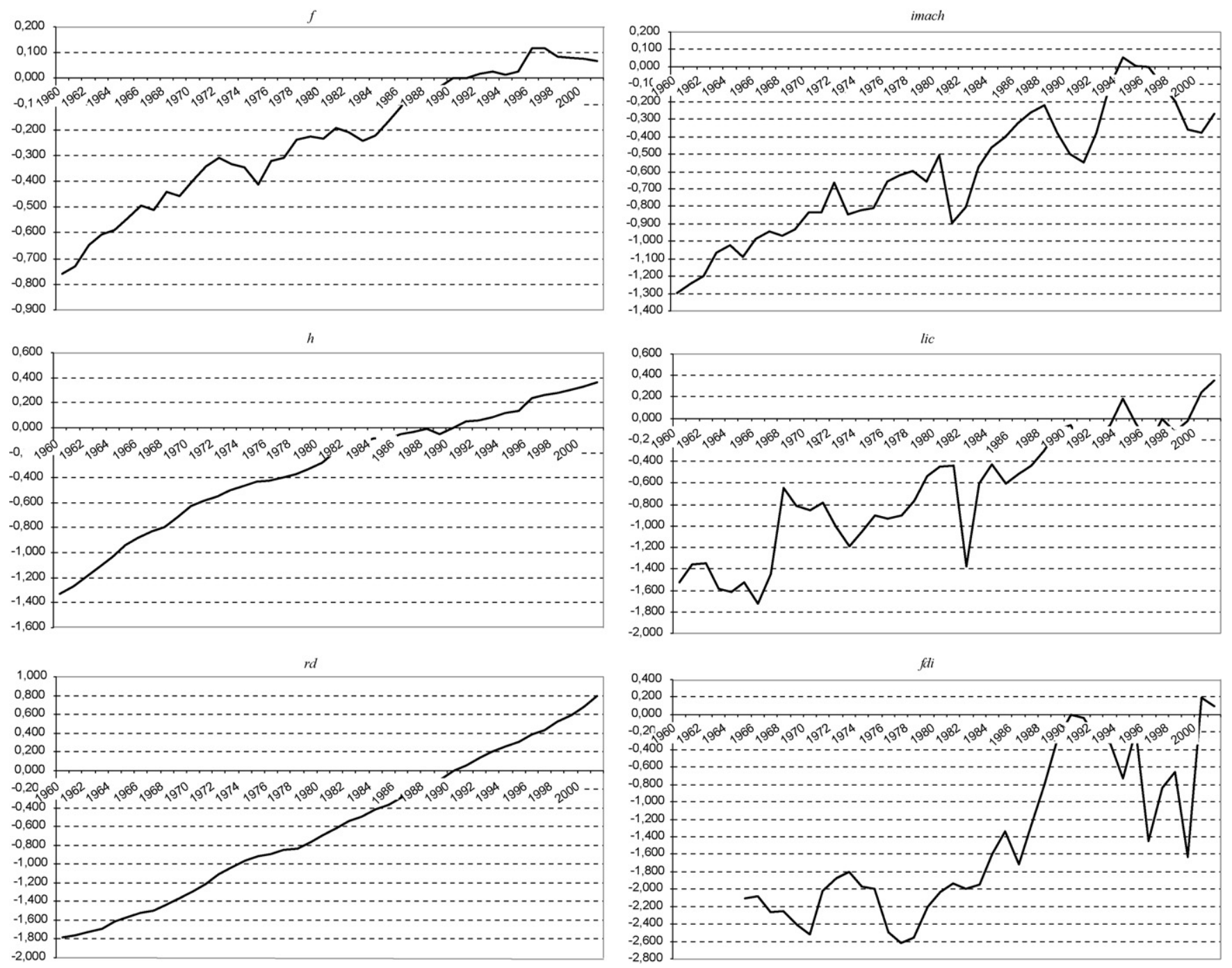

Fig. A1. Plots of the variables in levels.

complementary activities undertaken by science- and technologyrelated organizations-see OECD, 2008). ${ }^{10}$ It is crucial for the government to adopt a combined strategy in obtaining technology transfer from international trade, which at the same time moves towards developing the industries' technological capabilities, since technological progress is the driving force behind economic growth in the long run. Greater efforts could be made, for instance, to strengthen links between firms and public research institutions, improve the (advanced) training of workers, or direct research to the specific needs of certain industries (OECD, 2004). This would require purposeful joint strategic efforts from firms, industries, and the government. Indeed, implementing exclusively supplyside policy measures, aimed at unilaterally improving technology infrastructure, and adopting a passive intermediation perspective, a line which was followed in Portugal from the late 1980s until the mid-2000s (Laranja, 2009), are doomed to failure. In an institu-

\footnotetext{
10 By the end of the 1990s, beginning of 2000s, business R\&D efforts and the funding of R\&D efforts differed considerably among OECD countries (OECD, 2000): at one extreme (with high levels of R\&D and privately funded R\&D) were countries such as Japan and Korea, where the percentage of R\&D expenditure in GDP was over 2.5\%, and $70 \%$ of R\&D was funded by businesses; at the other extreme, were countries as Portugal, Argentina or Mexico, with corresponding figures below $0.5 \%$ (R\&D in GDP) and $20 \%$ (share of R\&D funded by businesses).
}

tional context such as that of Portugal, characterized by low levels of absorptive capacity on the part of business organizations, dominated by low-technology intensive, poorly organized production and processes, and which make an excessive use of poorly qualified workers (CSF III Observatory, 2007), demand-side policies can and should be actively used to improve the match between supply and demand, such as fostering the mobility of young researchers, improving career prospects for public researchers, providing better information to students on employment opportunities in the business sector, and undertaking efforts to increase business R\&D which would potentially create additional (high skilled) jobs in the business sector (OECD, 2004).

Our findings regarding the relevance of trade on the country's productivity clearly show that, as mentioned by Kim et al. (2009), the notion of desirable exports and undesirable imports may be misguided and counterproductive. In the case of Portugal, we find quite robust evidence in favour of the import-growth nexus. More specifically, we find that imports of certain capital goods have a significant positive impact on TFP. The unmistakable implication for Portuguese policymakers is the need to open further to foreign imports, which will help to bring about technological progress conducive to TFP growth.

The additional finding that FDI helps to promote economic growth in a complex and non-linear manner, with FDI flows being leveraged within the economy by key societal variables, namely the 
level of education, highlights the importance for countries undertaking policy measures aimed at encouraging domestic and foreign investment of the need to incorporate and consider broader social policy objectives - such as educational and institutional reforms - in order to take full advantage of the benefits deriving from inward FDI (Batten and Vo, 2009). Given the complementarities between local R\&D efforts and human capital accumulation (Aghion et al., 2009), our results further suggest that Portugal (and other countries sharing similar institutional developments) should place particular emphasis on attracting high-quality and technologically intensive FDI, and provide incentives for multinationals already located in the territory to upgrade production at their sites (Liu and Wang, 2003). The government should build on an economic environment conducive to encouraging (existing and forthcoming) multinationals to introduce advanced technology and conduct R\&D activities.

Despite some notable improvements at the end of the period 1960-2001, but in an astonishingly similar way to other (develop- ing) countries in Latin America and the Caribbean (LACs) (Alcorta and Peres, 1996) and Central and Eastern Europe (CEECs) (Svarc, 2006), technology accumulation, innovation capabilities and the productive use of local research capacity have been tremendously neglected by the Portuguese authorities. The technology-push strategy (lately) initiated by Portugal at the end of the 1980s and continued throughout the 1990s, heavily anchored in the European Structural Funds, overlooked the level of capabilities and corresponding supportive needs of the enterprise sector (Godinho and Simões, 2005). Portuguese authorities relied on a 'passive intermediation' (Laranja, 2009) which assumed that technology would spread unidirectionally, from advanced scientific R\&D to multiple applications in industry. It assumed additionally that the recipients had the capacity to absorb technological information, neglecting the provision of training and up-skilling to the recipient (Godinho and Simões, 2005; Laranja, 2009). Innovation policy was thus poorly understood and the building of a national innovation system was often overlooked in favour of other

Table A1

Time series used to compute relevant variables.

\begin{tabular}{|c|c|c|c|c|c|c|c|c|c|}
\hline Year $(t)$ & $\mathrm{GDP}_{t}$ & Labour $_{t}$ & $\begin{array}{l}\text { Physical } \\
\text { capital stock }_{t}\end{array}$ & TFP index $t_{t}$ & $\begin{array}{l}\text { Human } \\
\text { capital stock }_{t}\end{array}$ & $\begin{array}{l}\text { Business } \\
\text { R\&D stock }{ }_{t}\end{array}$ & $\begin{array}{l}\text { Ratio of machinery } \\
\text { and equip. imports } \\
\text { to GDP in } t-6\end{array}$ & $\begin{array}{l}\text { Ratio of licenses } \\
\text { and royalties to } \\
\text { GDP in } t-6\end{array}$ & $\begin{array}{l}\text { Ratio of inward } \\
\text { FDI to } \mathrm{GDP}_{t}\end{array}$ \\
\hline 1960 & $2,464,368$ & 3309 & 4919 & 0.468003 & 1.36 & 17,902 & 0.018 & 0.0004 & \\
\hline 1961 & $2,566,396$ & 3295 & 5047 & 0.482590 & 1.45 & 18,283 & 0.019 & 0.0004 & \\
\hline 1962 & $2,807,537$ & 3299 & 5137 & 0.523197 & 1.56 & 18,923 & 0.019 & 0.0003 & \\
\hline 1963 & $2,975,382$ & 3318 & 5287 & 0.545379 & 1.68 & 19,616 & 0.022 & 0.0003 & \\
\hline 1964 & $3,067,390$ & 3359 & 5350 & 0.555466 & 1.84 & 21,084 & 0.023 & 0.0004 & \\
\hline 1965 & $3,230,505$ & 3440 & 5286 & 0.580951 & 2.01 & 22,069 & 0.022 & 0.0003 & 0.006 \\
\hline 1966 & $3,518,268$ & 3518 & 5576 & 0.609727 & 2.13 & 23,212 & 0.024 & 0.0004 & 0.006 \\
\hline 1967 & $3,477,995$ & 3535 & 5591 & 0.600417 & 2.25 & 23,797 & 0.025 & 0.0009 & 0.005 \\
\hline 1968 & $3,818,754$ & 3550 & 5837 & 0.644640 & 2.33 & 25,494 & 0.025 & 0.0007 & 0.005 \\
\hline 1969 & $3,843,836$ & 3599 & 6051 & 0.633249 & 2.53 & 27,073 & 0.025 & 0.0007 & 0.004 \\
\hline 1970 & $4,199,176$ & 3637 & 6338 & 0.673102 & 2.74 & 29,114 & 0.028 & 0.0007 & 0.004 \\
\hline 1971 & $4,606,770$ & 3682 & 6795 & 0.709999 & 2.88 & 31,663 & 0.028 & 0.0006 & 0.006 \\
\hline 1972 & $4,983,097$ & 3748 & 7310 & 0.735084 & 2.98 & 34,968 & 0.033 & 0.0005 & 0.007 \\
\hline 1973 & $4,959,212$ & 3796 & 7562 & 0.715076 & 3.12 & 37,988 & 0.028 & 0.0006 & 0.008 \\
\hline 1974 & $5,000,901$ & 3781 & 7891 & 0.708289 & 3.23 & 40,644 & 0.028 & 0.0007 & 0.007 \\
\hline 1975 & $4,474,037$ & 3696 & 7369 & 0.662372 & 3.34 & 42,669 & 0.029 & 0.0006 & 0.007 \\
\hline 1976 & $4,774,313$ & 3624 & 7145 & 0.724586 & 3.38 & 43,440 & 0.033 & 0.0007 & 0.004 \\
\hline 1977 & $4,882,417$ & 3672 & 7171 & 0.734666 & 3.47 & 45,721 & 0.035 & 0.0008 & 0.004 \\
\hline 1978 & $5,393,675$ & 3770 & 7392 & 0.788996 & 3.55 & 46,022 & 0.036 & 0.0010 & 0.004 \\
\hline 1979 & $5,669,101$ & 3862 & 7837 & 0.796516 & 3.72 & 49,124 & 0.034 & 0.0010 & 0.005 \\
\hline 1980 & $5,683,577$ & 3944 & 7791 & 0.791993 & 3.91 & 53,144 & 0.039 & 0.0011 & 0.006 \\
\hline 1981 & $6,126,696$ & 3939 & 8417 & 0.823638 & 4.24 & 57,005 & 0.026 & 0.0004 & 0.007 \\
\hline 1982 & $6,218,352$ & 3965 & 8872 & 0.812669 & 4.41 & 61,873 & 0.029 & 0.0009 & 0.007 \\
\hline 1983 & $5,873,156$ & 3879 & 8675 & 0.784835 & 4.59 & 64,755 & 0.036 & 0.0011 & 0.007 \\
\hline 1984 & $5,926,447$ & 3937 & 8349 & 0.799996 & 4.74 & 70,469 & 0.041 & 0.0009 & 0.010 \\
\hline 1985 & $6,188,363$ & 3932 & 8185 & 0.843802 & 4.69 & 73,406 & 0.043 & 0.0010 & 0.013 \\
\hline 1986 & $6,529,012$ & 3900 & 8188 & 0.893951 & 4.90 & 79,342 & 0.047 & 0.0010 & 0.009 \\
\hline 1987 & $7,593,006$ & 4007 & 9106 & 0.974828 & 4.96 & 84,206 & 0.050 & 0.0012 & 0.014 \\
\hline 1988 & $7,727,170$ & 4096 & 9907 & 0.942369 & 5.10 & 90,532 & 0.052 & 0.0015 & 0.022 \\
\hline 1989 & $8,429,756$ & 4236 & 10823 & 0.968716 & 4.91 & 96,582 & 0.044 & 0.0015 & 0.036 \\
\hline 1990 & $9,047,713$ & 4279 & 11622 & 1.000000 & 5.15 & 106,187 & 0.039 & 0.0012 & 0.049 \\
\hline 1991 & $9,385,634$ & 4335 & 12329 & 1.001975 & 5.41 & 112,613 & 0.037 & 0.0014 & 0.047 \\
\hline 1992 & $9,849,644$ & 4360 & 13151 & 1.016960 & 5.46 & 121,509 & 0.044 & 0.0015 & 0.037 \\
\hline 1993 & $10,126,309$ & 4295 & 13904 & 1.026491 & 5.62 & 129,936 & 0.058 & 0.0020 & 0.035 \\
\hline 1994 & $10,130,336$ & 4293 & 14310 & 1.013318 & 5.80 & 137,969 & 0.068 & 0.0016 & 0.023 \\
\hline 1995 & $10,480,499$ & 4315 & 14837 & 1.027795 & 5.90 & 144,010 & 0.065 & 0.0013 & 0.041 \\
\hline 1996 & $11,724,515$ & 4251 & 15853 & 1.123343 & 6.53 & 155,963 & 0.065 & 0.0016 & 0.011 \\
\hline 1997 & $12,263,903$ & 4332 & 17011 & 1.125343 & 6.67 & 163,949 & 0.058 & 0.0014 & 0.021 \\
\hline 1998 & $12,823,638$ & 4739 & 18166 & 1.087946 & 6.82 & 179,202 & 0.053 & 0.0016 & 0.025 \\
\hline 1999 & $13,305,785$ & 4825 & 19444 & 1.082854 & 7.00 & 192,039 & 0.045 & 0.0021 & 0.010 \\
\hline 2000 & $13,793,738$ & 4909 & 20839 & 1.076714 & 7.19 & 209,356 & 0.044 & 0.0023 & 0.059 \\
\hline 2001 & $14,058,502$ & 4989 & 21638 & 1.068853 & 7.41 & 234,198 & 0.049 & 0.0022 & 0.054 \\
\hline
\end{tabular}

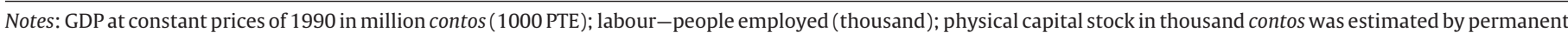

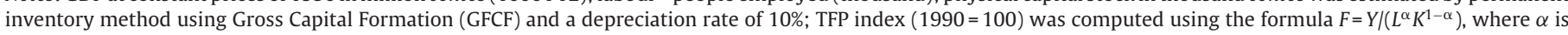

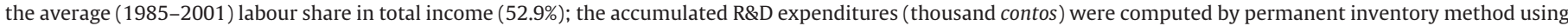

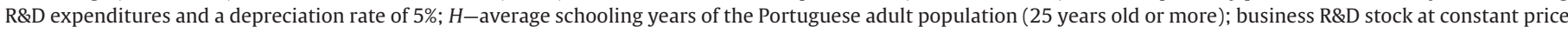
of 1990 in million contos (1000 PTE).

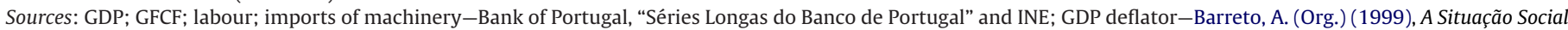

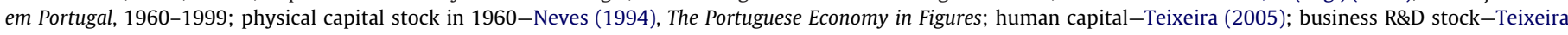
(2007); licenses and royalties; FDI: Bank of Portugal, "Séries Longas do Banco de Portugal" and INE. 
Table A2

Unit root tests-variables in second differences.

\begin{tabular}{|c|c|c|c|c|c|c|}
\hline Series & Mean & ADF test & Lags & $P$-value & PP test & $P$-value \\
\hline$f$ & -0.000950 & -4.805092 & 7 & 0.000019 & -27.008930 & 0.000000 \\
\hline$h$ & -0.000821 & -6.902036 & 1 & 0.000000 & -22.062327 & 0.000000 \\
\hline$r d$ & 0.002277 & -3.490426 & 6 & 0.000998 & -12.500714 & 0.000000 \\
\hline $\operatorname{imach}(t)$ & 0.001900 & -3.648280 & 9 & 0.000816 & -24.473292 & 0.000000 \\
\hline $\operatorname{imach}(t-6)$ & 0.001341 & -4.434826 & 9 & 0.000069 & -26.926831 & 0.000000 \\
\hline $\operatorname{lic}(t)$ & -0.023200 & -5.996858 & 4 & 0.000000 & -36.772229 & 0.000000 \\
\hline $\operatorname{lic}(t 6)$ & -0.001284 & -4.349054 & 9 & 0.000090 & -35.184290 & 0.000000 \\
\hline fdi & -0.003458 & -3.218752 & 8 & 0.002399 & -17.317984 & 0.000000 \\
\hline $\operatorname{himach}(t)$ & 0.003569 & -4.085838 & 9 & 0.000256 & -13.427084 & 0.000000 \\
\hline $\operatorname{himach}(t-6)$ & -0.000054 & -4.600368 & 9 & 0.000042 & -19.599191 & 0.000000 \\
\hline $\operatorname{rdimach}(t)$ & 0.003576 & -4.348813 & 9 & 0.000100 & -7.267008 & 0.000000 \\
\hline $\operatorname{rdimach}(t-6)$ & -0.002828 & -6.139487 & 9 & 0.000000 & -10.298884 & 0.000000 \\
\hline$h l i c(t)$ & -0.009009 & -5.368128 & 4 & 0.000002 & -31.152362 & 0.000000 \\
\hline$h l i c(t-6)$ & 0.003920 & -4.970120 & 4 & 0.000009 & -32.838581 & 0.000000 \\
\hline$h f d i$ & -0.002425 & -3.670454 & 8 & 0.000717 & -18.176063 & 0.000000 \\
\hline
\end{tabular}

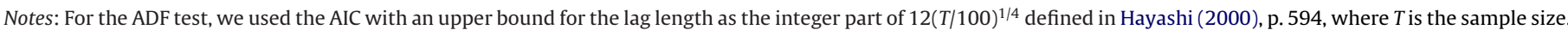

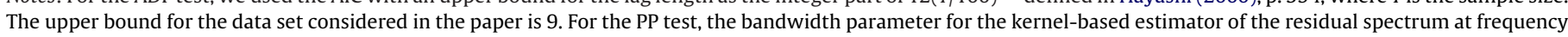

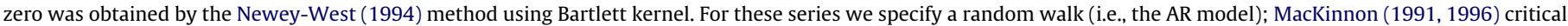
values for rejection of hypothesis of a unit root.

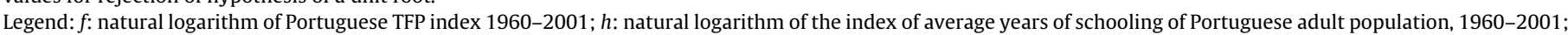

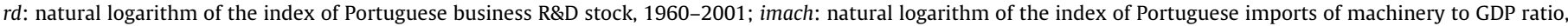

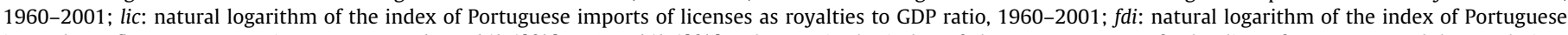

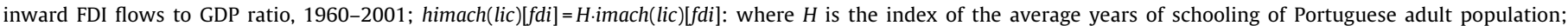
rdimach $=R D$.imach: where $R D$ is the index of the Portuguese business R\&D stock.

more politically and socially accepted priorities, namely macroeconomic stabilization, privatization, trade liberalization, and FDI (Mateus, 2005). As such, Portuguese science and technology institutions and organizations are far from performing an enabling role (Fagerberg and Godinho, 2005), links and interactions between government-backed organizations, businesses and academia are tenuous (Godinho and Simões, 2005; Teixeira and Costa, 2006), investment in intangibles and human capital remain one of the lowest among the EU Member States (Pereira and St Aubyn, 2009), and public policy is only partially effective (Macedo, 2007). It is necessary then to account for the matter of policy complementarities (Tavares and Teixeira, 2005). Given the time- and issue-interdependence of reforms, fragmented (piecemeal) pol- icy implementation creates fragilities, which can lead to crises and policy reversals (Macedo, 2007). Portugal's national innovation and institutional framework has been characterized by a proliferation of inadequately grounded policies, which are vulnerable to changes in the political cycle, excessively sectorized, and lack a systemic approach (Godinho and Simões, 2005; CSF III Observatory, 2007). The design of institutions, such as wagebargaining systems, flexibility in work organization and the nature of contractual arrangements, tax-benefit systems, the degree of labour mobility, the adaptability of the workforce, and the educational and training system, determine to a large extent the capacity of a system to swiftly absorb emerging imbalances and to adjust to changes in a competitive environment (EC, 2004). Unfortu-

Table A3

Unit root tests-variables in first differences.

\begin{tabular}{|c|c|c|c|c|c|c|}
\hline Series & Mean & ADF test & Lags & $P$-value & PP test & $P$-value \\
\hline$f$ & 0.020143 & -6.410431 & 0 & 0.000003 & -6.521405 & 0.000002 \\
\hline$h$ & 0.041294 & -4.505302 & 0 & 0.000838 & -4.556900 & 0.000722 \\
\hline$r d$ & 0.062714 & -3.327866 & 4 & 0.077930 & -5.226786 & 0.000635 \\
\hline $\operatorname{imach}(t)$ & 0.020390 & -0.955086 & 9 & 0.293856 & -5.486376 & 0.000002 \\
\hline $\operatorname{imach}(t-6)$ & 0.024986 & -1.247318 & 9 & 0.190474 & -5.649260 & 0.000000 \\
\hline $\operatorname{lic}(t)$ & 0.042281 & -6.803947 & 1 & 0.000000 & -10.505205 & 0.000000 \\
\hline $\operatorname{lic}(t-6)$ & 0.046018 & -6.351868 & 1 & 0.000000 & -8.147183 & 0.000000 \\
\hline$f d i$ & 0.061352 & -2.826095 & 3 & 0.006198 & -8.301826 & 0.000000 \\
\hline $\operatorname{himach}(t)$ & -0.001439 & -0.894976 & 9 & 0.318612 & -4.322061 & 0.000081 \\
\hline $\operatorname{himach}(t-6)$ & -0.005496 & -1.051937 & 9 & 0.257780 & -4.557052 & 0.000030 \\
\hline $\operatorname{rdimach}(t)$ & -0.005764 & -5.922493 & 6 & 0.000001 & -3.020870 & 0.003627 \\
\hline $\operatorname{rdimach}(t-6)$ & -0.015443 & -1.018489 & 9 & 0.270561 & -3.396824 & 0.001177 \\
\hline$h l i c(t)$ & 0.019262 & -6.321950 & 1 & 0.000000 & -8.218139 & 0.000000 \\
\hline$h l i c(t-6)$ & 0.022373 & -6.339995 & 1 & 0.000000 & -8.750811 & 0.000000 \\
\hline$h f d i$ & 0.026816 & -1.259684 & 9 & 0.185735 & -9.376338 & 0.000000 \\
\hline
\end{tabular}

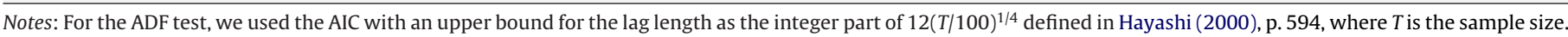

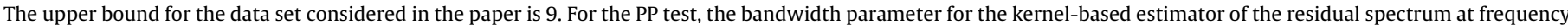

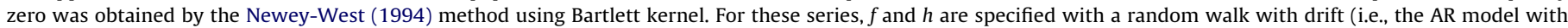

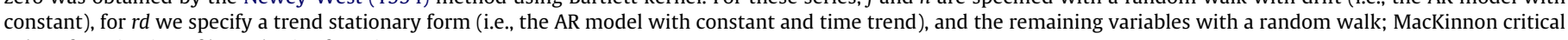
values for rejection of hypothesis of a unit root.

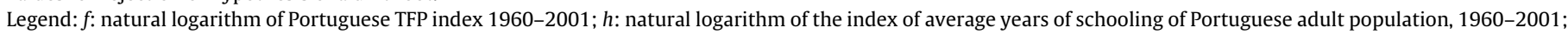

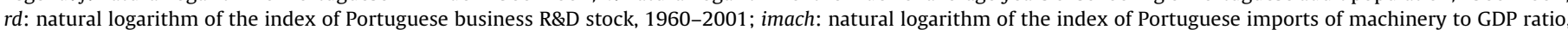

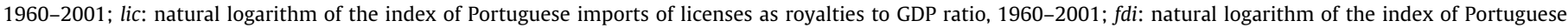

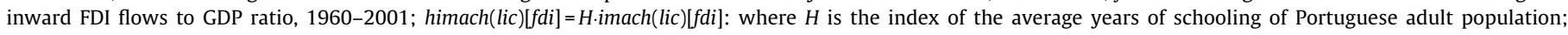
rdimach $=R D$.imach: where $R D$ is the index of the Portuguese business R\&D stock. 
Table A4

Unit root tests-variables in levels.

\begin{tabular}{|c|c|c|c|c|c|c|}
\hline Series & Mean & ADF test & Lags & $P$-value & PP test & $P$-value \\
\hline$f$ & -0.235272 & -2.773592 & 2 & 0.215071 & -2.559645 & 0.299770 \\
\hline$h$ & -0.324377 & -2.747141 & 0 & 0.224267 & -2.746944 & 0.224340 \\
\hline$r d$ & -0.603531 & -1.196167 & 5 & 0.896283 & -2.088494 & 0.536622 \\
\hline $\operatorname{imach}(t)$ & -0.521864 & -4.326477 & 4 & 0.009057 & -2.606929 & 0.279722 \\
\hline $\operatorname{imach}(t-6)$ & -0.611921 & -2.067238 & 7 & 0.544813 & -2.839720 & 0.192126 \\
\hline lic & -0.347503 & -4.493032 & 1 & 0.004741 & -5.210750 & 0.000638 \\
\hline lic6 & -0.665995 & -4.533848 & 0 & 0.004157 & -4.360938 & 0.006571 \\
\hline$f d i$ & -1.457576 & -3.187611 & 3 & 0.104292 & -3.179767 & 0.104487 \\
\hline $\operatorname{himach}(t)$ & -0.300462 & -3.262647 & 1 & 0.024831 & -2.564757 & 0.109760 \\
\hline $\operatorname{himach}(t-6)$ & -0.396784 & -0.910137 & 7 & 0.943165 & -2.686413 & 0.247222 \\
\hline $\operatorname{rdimach}(t)$ & -0.205251 & -4.813307 & 2 & 0.000462 & -2.509368 & 0.121928 \\
\hline $\operatorname{rdimach}(t-6)$ & -0.297259 & -1.472178 & 7 & 0.535326 & -1.147148 & 0.687767 \\
\hline$h l i c(t)$ & -0.117041 & -2.885022 & 0 & 0.177665 & -2.885022 & 0.177665 \\
\hline$h l i c(t-6)$ & -0.362727 & -3.123323 & 0 & 0.114591 & -3.103612 & 0.119005 \\
\hline hfdi & -1.062017 & -3.069642 & 3 & 0.129948 & -3.536307 & 0.050431 \\
\hline
\end{tabular}

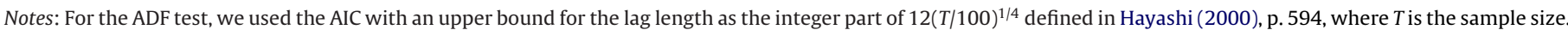

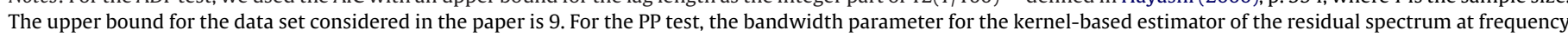

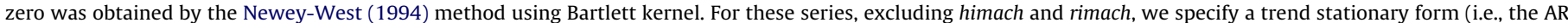

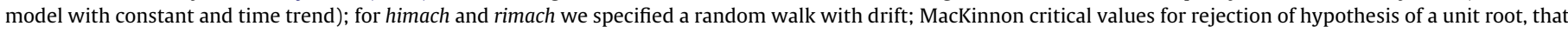
is non-stationarity.

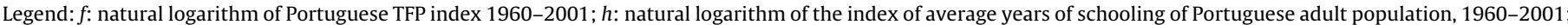

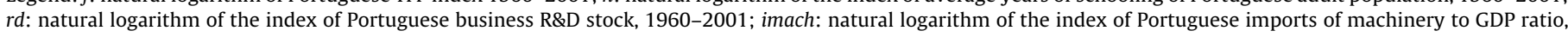

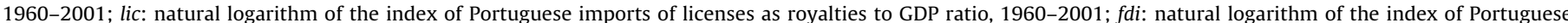

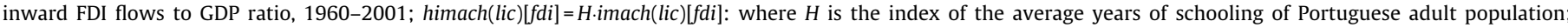
rdimach $=R D$.imach: where $R D$ is the index of the Portuguese business R\&D stock.

nately, in this regard, Portugal has also performed poorly (Tavares, 2004). ${ }^{11}$

As Mowery and Oxley (1995: 67) confirmed in their analysis of Japan and other East Asian economies, “... the economies that have benefited most from inward technology transfer have national innovation systems that have strengthened their 'national absorptive capacity"', where such a capacity has primarily relied on investments in scientific and technical training, and on sound, complementary and systemic economic policies that enforce competition among domestic firms. Of course, “... [it] is important to recognize that what works well in one country in one era may work quite differently in a different country or as times change, [which] makes prescription especially difficult." (Nelson, 2007: 323). Nevertheless, given that history matters (David, 2000) in these particulars, our findings on the Portuguese long-run economic process should not be ignored if the country aims to forge ahead instead of falling behind.

\section{Acknowledgements}

We are thankful for the insightful suggestions of two anonymous reviewers and the support and encouragement of the editor, Nick von Tunzelmann.

\section{Appendix A.}

See Fig. A1 and Tables A1-A4.

\footnotetext{
11 Portugal is usually classified as a country with rather restrictive employment protection legislation, constraining the ability of firms to react quickly to shocks. The stringency of this legislation has been shown to affect job and worker flows in Portugal, reducing turnover, limiting job creation and increasing unemployment duration (Blanchard and Portugal, 2001). Moreover, the low educational level of the labour force can get in the way of a smooth reallocation of labour across occupations, sectors and industries. Housing market restrictions and inefficient job-brokerage systems constitute additional hindrances for the mobility of workers (EC, 2004).
}

\section{References}

Abramovitz, M., 1986. Catching up, forging ahead, and falling behind. Journal of Economic History 46 (2), 385-406.

Afonso, O., Aguiar, A., 2005. Comércio Externo e Crescimento da Economia Portuguesa no Século XX. In: Pedro Lains e Álvaro Ferreira da Silva (org.) História Económica de Portugal (1700-2000), vol. III, O Século XX, Chapter 9. Instituto de Ciências Sociais da Universidade de Lisboa.

Aghion, P., David, P.A., Foraye, D., 2009. Science, technology and innovation for economic growth: linking policy research and practice in 'STIG Systems'. Research Policy 38, 681-693.

Alcorta, L., Peres, W., 1996. Innovation systems and technological specialization in Latin America and the Caribbean. Research Policy 26, 857-881.

Alfaro, L., Chanda, A., Kalemli-Ozcan, S., Sayek, S., 2004. FDI and economic growth: the role of local financial markets. Journal of International Economics 64, 89-112.

Archibugi, D., Cocoa, A., 2005. Measuring technological capabilities at the country level: a survey and a menu for choice. Research Policy 34, 175-194.

Athreye, S., Cantwell, J., 2007. Creating competition? Globalisation and the emergence of new technology producers. Research Policy 36, 209-226.

Aubert, J.E., Reiffers, J.L. (Eds.), 2003. Knowledge Economies in the Middle East and North Africa: Towards New Development Strategies. World Bank, Washington, DC.

Baer, W., Leite, A.N., 2003. The economy of Portugal within the European Union: 1990-2002. The Quarterly Review of Economics and Finance 43, 738-754.

Barreto, A. (Org.) (1999). A Situação Social em Portugal, 1960-1999. Lisboa: Imprensa de Ciências.

Barros, P.P., Garoupa, N., 1996. Portugal-European Union convergence: some evidence. European Journal of Political Economy 12, 545-553.

Batten, J.A., Vo, X.V., 2009. An analysis of the relationship between foreign direct investment and economic growth. Applied Economics 41, 1621-1641.

Ben-David, D., 1996. Trade and convergence among countries. Journal of International Economics 40, 279-298.

Benhabib, J., Spiegel, M., 1994. The role of human capital in economic development: evidence from aggregate cross-country data. Journal of Monetary Economics 34 143-173.

Birkinshaw, J., Hood, N., Jonsson, S., 1998. Building firm-specific advantages in multinational corporations: the role of subsidiary initiative. Strategic Management Journal 19 (3), 221-241.

Blanchard, O., Portugal, P., 2001. What hides behind an unemployment rate: comparing Portuguese and U.S. labor markets. American Economic Review 91 (1), 187-207.

Blomström, M., Kokko, A., Globerman, S., 2001. The determinants of host country spillovers from foreign direct investment: a review and synthesis of the literature. In: Pain, N. (Ed.), Inward Investment, Technological Change and Growth. The Impact of Multinational Corporations on the UK Economy. Palgrave, Houndmills.

Borensztein, E., De Gregorio, J., Lee, J.-W., 1998. How does foreign direct investment affect economic growth. Journal of International Economics 45 115-135.

Breschi, S., Lissoni, F., 2001. Knowledge spillovers and local innovation systems: a critical survey. Industrial and Corporate Change 10 (4), 975-1075. 
Cantwell, J.A., 1989. Technological Innovation and Multinational Corporations. Basil Blackwell, Oxford.

Castro, F.B., 2004. Foreign direct investment in a late industrializing country: the Portuguese IDP revisited. FEP Working Paper No. 147, May 2004.

Chakraborty, C., Nunnenkamp, P., 2008. Economic reforms, FDI, and economic growth in India: a sector level analysis. World Development 36 (7), 1192-1212.

Chong, A., Zanforlin, L., 2002. Technology and epidemics. IMF Staff Papers 49 (3), 426-455.

Coe, D.T., Helpman, E., 1995. International R\&D spillovers. European Economic Review 39, 859-887.

Coe, D.T., Helpman, E., Hoffmaister, A.W., 1997. North and South spillovers. Economic Journal 107, 134-149.

Cohen, W.M., Levinthal, D.A., 1989. Innovation and learning: the two faces of R\&D. The Economic Journal 99 (397), 569-596.

Courakis, A.S., Roque, F.M., Fontoura, P., 1990. The Impact of Protection on the Evolution of the Portuguese Pattern of Trade: 1974-86. Working Paper 162. Universidade Nova de Lisboa, Dezembro.

CSF III Observatory, 2007. National Strategic Reference Framework-Portugal 2007-2013. Ministry of the Environment, Spatial Planning and Regional Development, Lisbon.

David, P.D., 2000. Path dependence, its critics and the quest for 'historical economics'. In: Garrouste, P., Ioannides, S. (Eds.), Evolution and Path Dependence in Economic Ideas: Past and Present. Edward, Elgar Publishing, Cheltenham, England.

Dibooglu, S., Enders, W., 1995. Multiple cointegrating vectors and structural economic models: an application to the French Franc/US dollar exchange rate. Southern Economic Journal 61 (4), 1098-1116.

Dickey, D., Jansen, D., Thornton, D., 1991. A primer on cointegration with an application to money and income. In: Rao, B. (Ed.), Cointegration for the Applied Economist. Macmillan, Basingstoke, pp. 58-78.

Dickey, D., Fuller, W., 1981. Likelihood ratio statistics for autoregressive time series with a unit root. Econometrica 49, 1057-1072.

Dollar, D., 1992. Outward-oriented developing economies really do grow more rapidly: evidence from 95 LDCs, 1976-85. Economic Development and Cultural Change 40 (3), 523-544.

EC, 2004. The Portuguese Economy after the Boom. Occasional Papers No. 8. European Commission, Directorate-General for Economic and Financial Affairs, Brussels.

Engle, R., Granger, C., 1987. Co-integration and error correction: representation, estimation and testing. Econometrica 55, 251-276.

Fabrizio, K., 2009. Absorptive capacity and the search for innovation. Research Policy $38,255-267$.

Fagerberg, J., Verspagen, B., 2002. Technology-gaps, innovation-diffusion and transformation: an evolutionary interpretation. Research Policy 31, 1291-1304.

Fagerberg, J., 1987. A technology gap approach to why growth rates differ. Research Policy 16, 87-99.

Fagerberg, J., Godinho, M.M., 2005. Innovation and catching-up. In: Fagerberg, J., Mowery, D., Nelson, R. (Eds.), The Oxford Handbook of Innovation. Oxford University Press, New York.

Freeman, C., 1987. Technology Policy and Economic Performance: Lessons from Japan. Frances Pinter, London.

Furman, J.L., Porter, M.E., Stern, S., 2002. The determinant of national innovative capacity. Research Policy 31, 899-933.

Gershenberg, I., 1987. The Training and Spread of Managerial Know-how: a comparative analysis of multinational and other firms in Kenya. World Development 15, 931-939.

Girma, S., 2005. Absorptive capacity and productivity spillovers from FDI. A threshold regression analysis. Oxford Bulletin of Economics and Statistics 67, 281-306.

Glass, A., Saggi, K., 1998. International technology transfer and the technology gap. Journal of Development Economics 55, 369-398.

Godinho, M., Simões, V., 2005. I\&D, Inovação e Empreendedorismo 2007-2013. In: Relatório Final. Estudo foi realizado por uma equipa do ISEG para o Observatório do QCA III, ISEG, Julho de 2005.

Gonçalves, O.F., 1998. Convergência Real no Longo Prazo da Economia Portuguesa. Notas Económicas 11, 82-100.

Gonçalves, O.F., Guimarães, P., 1997. O investimento directo estrangeiro na indústria transformadora Portuguesa: uma abordagem sectorial e regional atraveǐ s do emprego para o período 1982-1992. Estudos de Economia 16-17 (3), 333-358.

Granger, C., Newbold, P., 1974. Spurious regressions in econometrics. Journal of Econometrics 2, 111-120.

Griffith, R., Redding, S., Reenen, J., 2003. R\&D and absorptive capacity: theory and empirical evidence. Scandinavian Journal of Economics 105 (1), 99-118.

Griliches, Z., 1988. Productivity puzzles and R\&D: another nonexplanation. Journal of Economic Perspectives 2 (4), 9-21.

Grossman, G., Helpman, E., 1991. Innovation and Growth in the Global, Economy. MIT Press.

Haddad, M., Harrison, A., 1993. Are there positive spillovers from direct foreign investment? Evidence from panel data for Morocco. Journal of Development Economics 42, 51-74.

Hayashi, F., 2000. Econometrics. Princeton University Press, Princeton.

Hermes, N., Lensink, R., 2003. Foreign direct investment, financial development and economic growth. Journal of Development Studies 40, 142-163.

Johansen, S., Juselius, K., 1990. Maximum likelihood estimation and inference on cointegration with application to the demand for money. Oxford Bulletin of Economics and Statistics 52, 169-209.

Jones, C., 1995. Time series tests of endogenous growth models. Quarterly Journal of Economics 110 (2), 495-525.
Kim, L., Dahlman, C., 1992. Technology policy for industrialization: an integrative framework and Korea's experience. Research Policy 21, 437-452.

Kim, S., Lim, H., Park, D., 2009. Imports, exports and total factor productivity in Korea. Applied Economics 41, 1819-1834.

Kocherlakota, N., Yi, K.-M., 1997. Is there Endogenous Long-Run Growth? Evidence from the United States and the United Kingdom. Journal of Money Credit and Banking 29, 235-262.

Krugman, P., Macedo, J.B., 1979. The economic consequences of the April 25th revolution. Economia 3 (3), 455-483.

Lains, P., 2003. Catching-up to the European core: Portuguese economic growth, 1910-1990. Explorations in Economic History 40, 369-386.

Laranja, M., 2009. The development of technology infrastructure in Portugal and the need to pull innovation using proactive intermediation policies. Technovation 29, 23-34.

Lawrence, R., Weinstein, D., 1999. Trade and growth: import-led or export-led? Evidence from Japan and Korea. NBER Working Paper No. 7264.

Liu, X., Wang, C., 2003. Does foreign direct investment facilitate technological progress? Evidence from Chinese industries. Research Policy 32, 945-953.

Lopes, J.S., 1996. A Economia Portuguesa Desde 1960. Gradiva.

Lundvall, B.A., 1992. National Systems of Innovation. Towards a Theory of Innovation and Interactive Learning. Pinter, London.

Macedo, J.B., 2007. Competitiveness and convergence in Portugal. GEE Papers No. 4, November de 2007.

MacKinnon, J., 1991. Critical values for cointegration tests. In: Engle, R., Granger, C. (Eds.), Long-run economic relationships: readings in cointegration. Oxford University Press, Oxford.

MacKinnon, J., 1996. Numerical distribution functions for unit root and cointegration tests. Journal of Applied Econometrics 11, 601-618.

MacKinnon, J., Haug, A., Michelis, L., 1999. Numerical distribution functions of likelihood ratio tests for cointegration. Journal of Applied Econometrics 14, 563-577.

Mankiw, N., Romer, D., Weil, D., 1992. A contribution to the empirics of economic growth. Quarterly Journal of Economics 107 (2), 407-437.

Markusen, J.R., Venables, A., 1999. Foreign direct investment as a catalyst for industrial development. European Economic Review 43, 335-356.

Mateus, A., 2005. A internacionalização da economia. In: Lains, P., Silva, A.F. (orgs.), História Económica de Portugal 1700-2000, vol. III, O século XX. Instituto Ciências Sociais, Lisboa, pp. 125-156.

Mayer, J., 2001. Technology diffusion, human capital and economic growth in developing countries. UNCTAD Discussion Papers No. 154, June 2001.

Mendi, P., 2007. Trade in disembodied technology and total factor productivity in OECD countries. Research Policy 36, 121-133.

Meyer, K., 2003. FDI spillovers in emerging markets: a literature review and new perspectives. DRC working paper 15. Copenhagen Business School.

Mowery, D., Oxley, J., 1995. Inward technology transfer and competitiveness: the role of national innovation systems. Cambridge Journal of Economics 19 (1), 67-93.

Narula, R., Dunning, J., 2000. Industrial development, globalization and multinational enterprises: new realities for developing countries. Oxford Development Studies 28, 141-167.

Nelson, R., 2007. Institutions and economic growth: sharpening the research agenda. Remarks upon receipt of the Veblen-Commons Award. Journal of Economic Issues 41 (2), 994-1005.

Nelson, R.R. (Ed.), 1993. National Innovation Systems. Oxford University Press, Oxford and New York.

Nelson, R.R., Phelps, E.S., 1966. Investment in humans, technological diffusion and economic growth. American Economic Review LVI (2), 69-75.

Neves, J.C., 1994. The Portuguese Economy: a Picture in Figures. XIX and. XX centuries. Lisbon, Universidade Católica Editora.

Newey, W.K., West, K.D., 1994. Automatic Lag Selection in Covariance Matrix Estimation. Review of Economic Studies 61, 631-653.

OECD, 1999. OECD Science, Technology and Industry-Scoreboard 1999Benchmarking Knowledge-based Economies. http://www.oecd.org/dataoecd/ 42/53/2087228.pdf (accessed on August 2009).

OECD, 2000. OECD Science, Technology and Industry. Outlook 2000: Highlights. OECD Publications Service, Paris.

OECD, 2003. OECD Economic survey Portugal Structural reform for sustaining high growth. OECD Economic Surveys 2003 (2), 198-288.

OECD, 2004. OECD Science, Technology and Industry. Outlook 2004: Highlights. OECD Publications Service, Paris.

OECD, June 2008. OECD Economic Surveys, vol. 2008/9. OECD, Portugal.

Pack, H., 1994. Endogenous growth theory: intellectual appeal and empirical shortcomings. Journal of Economic Perspectives 8 (1), 55-72.

Pearce, R.D., 1999. The evolution of technology in multinational enterprises: the role of creative subsidiaries. International Business Review 8, 125-148.

Pereira, J., St Aubyn, M., 2009. What level of education matters most for growth? Evidence from Portugal. Economics of Education Review 28 (1), 67-73.

Phillips, P., Perron, P., 1988. Testing for a unit root in time series regression. Biometrica $75,335-346$.

Rao, B., 1994. Cointegration: For the Applied Economist. Macmillan, Basingstoke.

Rivera-Batiz, Luis, A., Xie, D., 1993. Integration among unequals. Regional Science and Urban Economics 23 (3), 337-354.

Savvides, A., Zachariadis, M., 2005. International technology diffusion and the growth of TFP in the manufacturing sector of developing economies. Review of Development Economics 9 (4), 482-501. 
Silva, E., Teixeira, A.A.C., 2009. Does structure influence growth? A panel data econometric assessment of 'relatively less developed' countries, 1979-2003. Industrial and Corporate Change, Forthcoming.

Stanisic, N., 2008. Do foreign direct investments increase the economic growth of southeastern european transition economies? South-Eastern Europe Journal of Economics 1, 29-38.

Svarc, J., 2006. Socio-political factors and the failure of innovation policy in Croatia as a country in transition. Research Policy 35, 144-159.

Tavares, A.T., Young, S., 2005. FDI and multinationals: patterns, impact and policies. International Journal of the Economics of Business 12 (1), 3-16.

Tavares, A.T., Teixeira, A.A.C., 2005. Human capital intensity in technology-based firms located in Portugal: do foreign multinationals matter? FEP Working Papers No. 187. Faculdade de Economia, Universidade do Porto.

Tavares, J., 2004. Institutions and economic growth in Portugal: a quantitative exploration. Portugal Economic Journal 3, 49-79.

Teixeira, A.A.C., 2005. Measuring aggregate human capital in Portugal, 1960-2001. Portuguese Journal of Social Science 4 (2), 101-120.

Teixeira, A.A.C., 2007. How has the Portuguese innovation capability evolved? Estimating a time series of the stock of technological knowledge, 1960-2001. Portuguese Journal of Social Science 6 (2), 77-95.

Teixeira, A.A.C., Costa, J., 2006. What type of firm forges closer innovation linkages with Portuguese Universities? Notas Económicas 24, 22-47.
Teixeira, A.A.C., Fortuna, N., 2004. Human capital, innovation capability and economic growth Portugal, 1960-2001. Portuguese Economic Journal 3 (3) 205-225.

Verspagen, B., 1993. Uneven Growth Between Interdependent Economies: An Evolutionary View on Technology Gaps, Trade and Growth. Avebury, Aldershot.

Wang, C., Yu, L., 2007. Do spillover benefits grow with rising foreign direct investment? An empirical examination of the case of China. Applied Economics 39, 397-405.

Wang, J., Blomström, M., 1992. Foreign investment and technology transfer. European Economic Review 36, 137-155.

Wößmann, L., 2003. Specifying human capital. Journal of Economic Surveys 17 (3), 239-270.

$\mathrm{Xu}, \mathrm{B} ., 2000$. Multinational enterprises, technology diffusion, and host country productivity growth. Journal of Development Economics 62, 477-493.

Xu, B., Chiang, E., 2005. Trade, patents and international technology diffusion. Journal of International Trade and Economic Development 14 (1), 115-135.

$\mathrm{Xu}, \mathrm{B} .$, Wang, J., 2000. Trade, foreign direct investment and international technology diffusion. Journal of Economic Integration 15 (4), 585-601.

Zhu, L., Jeon, B., 2007. International R\&D spillovers: trade, FDI, and information technology as spillover channels. Review of International Economics 15 (5) 955-976. 